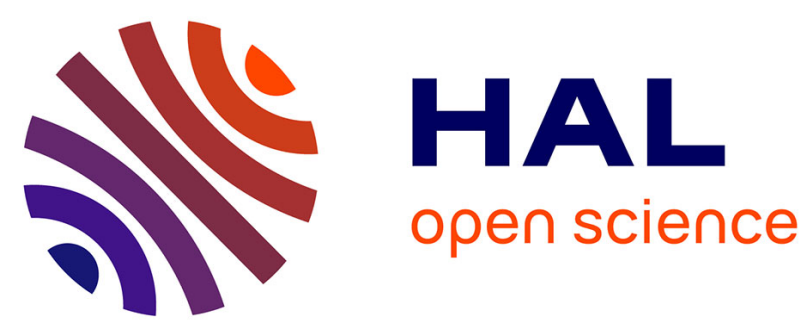

\title{
Seasonal variation in oestrogenic potency and biological effects of wastewater treatment works effluents assessed using ERE-GFP transgenic zebrafish embryo-larvae
} Ruth Cooper, Arthur David, Tetsuhiro Kudoh, Charles R Tyler

\section{- To cite this version:}

Ruth Cooper, Arthur David, Tetsuhiro Kudoh, Charles R Tyler. Seasonal variation in oestrogenic potency and biological effects of wastewater treatment works effluents assessed using ERE-GFP transgenic zebrafish embryo-larvae. Aquatic Toxicology, 2021, 237, pp.105864. 10.1016/j.aquatox.2021.105864 . hal-03268657

\section{HAL Id: hal-03268657 https://hal.science/hal-03268657}

Submitted on 1 Jul 2021

HAL is a multi-disciplinary open access archive for the deposit and dissemination of scientific research documents, whether they are published or not. The documents may come from teaching and research institutions in France or abroad, or from public or private research centers.
L'archive ouverte pluridisciplinaire HAL, est destinée au dépôt et à la diffusion de documents scientifiques de niveau recherche, publiés ou non, émanant des établissements d'enseignement et de recherche français ou étrangers, des laboratoires publics ou privés. 
Seasonal variation in oestrogenic potency and biological effects of wastewater treatment works effluents assessed using ERE-GFP transgenic zebrafish embryo-larvae.

Ruth Cooper $^{a^{*}}$, Arthur David $^{\mathrm{b}}{ }^{1},{ }$, Tetsuhiro Kudoh ${ }^{\mathrm{a}}$ and Charles R. Tyler ${ }^{\mathrm{a*}}$

a Biosciences, College of Life and Environmental Sciences, University of Exeter, Exeter, U.K. University of Sussex, School of Life Sciences, Brighton BN1 9QJ, United Kingdom

Address for correspondence: Charles R. Tyler, Biosciences, College of Life and Environmental Sciences, Geoffrey Pope Building, University of Exeter, Exeter, Devon, EX4 4QD, UK.

Phone +44 (0)1392 264450;

Email: C.R.Tyler@exeter.ac.uk

\section{Abstract}

Effluents from wastewater treatment works (WwTW) exhibit both temporal and spatial variation in oestrogenicity, however few studies have attempted to quantify how this variation affects biological responses in fish. Here we used an oestrogen-responsive green fluorescent protein (ERE-GFP) transgenic zebrafish (Danio rerio) to quantify oestrogenic activity and health effects for exposure to three different WwTW effluents.

\footnotetext{
${ }^{1}$ Univ Rennes, Inserm, EHESP, Irset (Institut de recherche en santé, environnement et travail) - UMR_S 1085, F35000 Rennes, France
} 
Endpoints measured included survival/hatching rate, GFP induction (measured in target tissues or gfp mRNA induction in whole embryos) and vtg mRNA induction in whole embryos. Exposure to one of the study effluents (at 100\%), resulted in some mortality, and exposure to all three effluents (at 50\% and 100\%) caused decreases in hatching rates. Higher levels of vtg mRNA corresponded with higher levels of steroidal oestrogens in the different effluents, with lowest-observed-effect concentrations (LOECs) between $31 \mathrm{ng} / \mathrm{L}$ and $39 \mathrm{ng} / \mathrm{L}$ oestradiol equivalents (EEQs). Tissue patterns of GFP expression for all three WwTWs effluents reflected the known targets for steroidal oestrogens and for some other oestrogenic chemicals likely present in those effluents (i.e. nonylphenol or bisphenolic compounds). GFP induction was similarly responsive to vtg mRNA induction (a well-established biomarker for oestrogen exposure). We thus demonstrate the ERE-GFP transgenic zebrafish as an effective model for monitoring the oestrogenic potency and health effects for exposure to complex mixtures of chemicals contained within WwTW effluents.

Cooper et al_Highlights

- ERE-GFP zebrafish applied to quantify the oestrogenicity of WwTW effluents.

- GFP tissue patterning was reflective of the oestrogenic content of the WwTW effluents.

- Tissue oestrogenic responses varied seasonally and between different WwTW effluents.

- GFP induction was similarly responsive to vtg mRNA induction.

- ERE-GFP zebrafish provide an effective biosensor for health effects monitoring of complex mixtures.

\section{Introduction}

Globally, it has been estimated that each year over $450 \mathrm{~km}^{3}$ of domestic, industrial and agricultural wastewater is released into our aquatic environments, which in turn 
requires $6000 \mathrm{~km}^{3}$ of freshwater for treatment - an amount equivalent to two thirds of the world's usable surface freshwater (Shiklomanov, 2000). Dilution of these wastewaters varies both regionally and seasonally, and in some instances, effluents are released undiluted (and even untreated) into natural freshwaters (Corcoran et al., 2010). As the demand for clean water increases, and because of uncertainties in freshwater supply due to climate change, this will put further pressures on the use of freshwater for the dilution of effluent discharges and thus potential threats of Wastewater Treatment Work (WwTW) effluents to aquatic wildlife are of increasing global concern.

Evidence from both field and laboratory studies have shown a clear link between exposures to WwTW effluents and adverse health effects in aquatic wildlife. In fish, these effects include altered reproductive development (Tetreault et al., 2012; Thorpe et al., 2009), genotoxic damage (Rocco et al., 2012; Wilhelm et al., 2018), alterations in immune function (Borgia et al., 2018; Liney et al., 2006), cytotoxic and oxidative damage (Gagné et al., 2006; Lacaze et al., 2017b), nephrotoxicity (Liney et al., 2006) and alterations in behaviour (Gauthier and Vijayan, 2020; McCallum et al., 2017).

Effluents from WwTWs contain highly complex mixtures of chemicals, comprising of both natural and synthetic organic substances, metals and trace elements, making it inherently difficult to establish specific chemical cause and effect relationships for the health conditions seen in exposed aquatic wildlife. Reported disruptions in reproductive processes in fish exposed to these effluents, that have included altered sex hormone levels (Jeffries et al., 2008; Lacaze et al., 2017a), intersexuality and demasculinisation (Bahamonde et al., 2015a, 2015b; Sanchez et al., 2011), decreased gamete production and reduced fertility (Cavallin et al., 2016; Teta and 
Naik, 2017), have been shown to be caused by endocrine disrupting chemicals (EDCs).

Steroidal oestrogens (both natural and synthetic) are some of the most potent EDCs found in WwTW effluents and many studies have confirmed their ability to disrupt sexual development and reproduction in freshwater fish, including for environmentally relevant exposures (Kidd et al., 2007; Schwindt et al., 2014). In humans, it has been suggested that exposure to oestrogenic chemicals can result in reduced sperm count/quality, disruptions in the development of the reproductive tract and oestrogen dependent cancers (Jørgensen et al., 2012; Yuan et al., 2019) as well as effects on the immune system, obesity and cardiovascular disease (Hatch et al., 2010; Lang et al., 2008; Sweeney and Voelkel, 2009).

The oestrogenic activity of WwTW effluents varies temporally and is influenced by the composition of the wastewater entering the works, the type of treatment process employed (Ben et al., 2018; Sun et al., 2017), levels of rainfall, and in temperate climates by seasonal differences in temperature that can affect both the types of microorganism present and their efficacy in biodegrading chemicals (Cruikshank and Gilles, 2007; Phillips et al., 2012). Various in vitro assay systems have been adopted for the screening and monitoring of environmental oestrogens in WwTWs including the yeast oestrogen screen (YES) assay (Routledge and Sumpter, 1996) and E-Screen assay (Legler et al., 1999) both of which involve a single oestrogen receptor (ER) subtype (there are two ERs in humans - ER $\alpha$ and ER $\beta$, and three forms in fish ESR1, ESR $\beta 1$, ESR $\beta 2$ ). These assays provide information on levels of oestrogen activity at the level of a single receptor interaction site but extrapolation to possible health effects is extremely difficult. More recently, several transgenic biosensor fish lines have been developed for testing for oestrogenic activity that are both sensitive to 
estrogen exposure and can provide deeper insights into the potential health impacts of oestrogenic compounds and their mixtures (Bakos et al., 2019; Green et al., 2018, 2016; Lee et al., 2012). Transgenic biosensor fish lines can also be used to support the adverse outcome pathway (AOP) framework because they enable direct links to be drawn between binding and activation of a specific receptor or enzyme and a phenotypic outcome (e.g. Brown et al., 2019).

In this study, we applied an oestrogen responsive element (ERE) - green fluorescent protein (GFP) transgenic zebrafish (Danio rerio) (Lee et al., 2012), that detects oestrogenic responses for all three ER subtypes, to investigate for responding target tissues and health effects for exposure to three different WwTW effluents at two dilutions (50 and 100\%) at time points over the course of a year. Exposures to $10 \mathrm{ng} / \mathrm{L}$ EE2 were included in each experiment serving as a positive control. We also compared the sensitivity of the fluorescence responses in the transgenic zebrafish model with vitellogenin (VTG) mRNA induction, a well-established biomarker for oestrogen exposure in fish, for the effluent and EE2 exposures.

\section{Materials and methods}

\subsection{Test Animals and Husbandry}

All fish were maintained under approved protocols, according to the UK Home Office regulations for the use of animals in scientific procedures. Stock ERE-GFP transgenic zebrafish (developed at the University of Exeter; 3×ERE:Gal4ff and UAS:GFP; (Lee et al., 2012)) employed in this study were raised under the following conditions: water temperature $28.5 \pm 1^{\circ} \mathrm{C}$, with a 12-hr light, 12-hr dark cycle photoperiod regime with gradual dawn and dusk transitions of 30 minutes. Fish were fed live newly hatched Brine Shrimp (Artemia) and frozen Gamma Omega 3 Enriched 
Brineshrimp (supplied by Zebrafish Management Ltd., Wincester, UK). The supply of water to the laboratory aquaria was subjected to reverse-osmosis with subsequent addition of salts (as described in OECD Guideline 203; (OECD, 2019)). In the experimental exposures (monitored daily) the aquarium water temperature ranged between 26.5 and $27.6^{\circ} \mathrm{C}$, the $\mathrm{pH}$ ranged between 6.8 and 7.7 , the water conductivity was between 200 and $255 \mu \mathrm{S} / \mathrm{cm}$ and the dissolved oxygen concentrations were > $80 \%$ of the air saturation value.

\subsection{Study WwTWs effluents and effluent collection}

We studied the effluents from three WWTWs located in England. The total and industrial population equivalent (PE; or unit per capita loading is a means of quantifying the organic strength of wastewater discharges and reflects the net waste of the surrounding human population and industrial facilities, which in the European Union countries is based on a biological oxygen demand (BOD) of the water of $60 \mathrm{~g}$ per person/per day). PEs for each of the WwTWs were obtained from the water utility responsible for their operation. The WwTWs studied here are typical of those found in the UK, in that they receive waste primarily from domestic sources, with some industrial/trade waste also. Full details of total population equivalent, types of treatment processes and the types of industrial/trade discharges at each site are provided in Table 1. Dissolved oxygen concentrations for all consignments of effluent were above $80 \%$, and $\mathrm{pH}$ values for the effluent consignments ranged between 6.5 and 7.2 for WwTW1, 6.9 and 7.3 for WwTW2 and 7.4 and 7.7 for WwTW3. Conductivity ranged from 590-980 $\mu \mathrm{S} / \mathrm{cm}$ for WwTW1, $4122-7173 \mu \mathrm{S} / \mathrm{cm}$ for WwTW2 and $460-590 \mu \mathrm{S} / \mathrm{cm}$ for WwTW3. A range of physiochemical parameters were measured, including temperature, rainfall, dissolved/suspended solids, nitrogen and 
phosphorus levels, and biochemical and chemical oxygen demand (BOD/COD) concentrations and are provided in Table 1.

Samples for both analytical chemistry and for embryo-larval exposures comprised of 24-hr WwTW effluent composites (10 L per sampling occasion) collected four times a week from the study sites. Samples were collected using an automatic sampler, in which the sampling frequency was set to every $20 \mathrm{~min}$ (i.e. 72 individual grab samples in total/24 hr). All samples were subsequently transferred to $2.5 \mathrm{~L}$ glass Winchester bottles, that had been previously acid washed and rinsed with acetone (analytical reagent grade, Fisher Chemicals, Loughborough, UK) and dichloromethane (HPLC grade, Fisher Chemicals), to remove any traces of contaminants, and immediately transported back to the university in cool boxes. Upon arrival at the lab, samples needed for the fish exposure work were slowly acclimated to the desired test temperature of $28^{\circ} \mathrm{C}$, stirred and aerated $1 \mathrm{hr}$ prior to exposure, and remaining samples were stored at $4{ }^{\circ} \mathrm{C}$ to minimise the risk of oestrogen degradation until required for renewal of the exposure medium.

2.3Analytical measurement of concentrations of oestrogenic chemicals; Estrone (E1), 17ß-estradiol (E2), and 17a-ethinylestradiol (EE2)

Analytical chemistry was conducted for all WwTW sample collections. For this, $3 \mathrm{~L}$ of effluent samples were stabilised immediately upon collection of the WwTW effluent with methanol (HPLC grade, Fisher Chemicals; $5 \%$ final concentration) and acetic acid (HPLC grade, Fisher Chemicals; $1 \%$ final concentration) and stored at $4{ }^{\circ} \mathrm{C}$ prior to Solid Phase Extraction (SPE). The $24 \mathrm{hr}$ composite samples were divided into three 1 $\mathrm{L}$ replicates and spiked with internal standards (ISTDs) containing deuterated estrone(E1d4), deuterated 17ß-estradiol (E2d4) and deuterated 17a-ethinyloestradiol 
(EE2d4). Deuterated E1d4 and E2d4 were obtained from CDN Isotopes (Quebec, Canada), and EE2d4 from Cambridge Isotope Labs (Andover, MA, USA). The samples spiked with ISTD were then pre-filtered through glass wool and filter paper Whatman No1 (Whatman, Maidstone, UK) to remove any large particulates, prior to extraction onto pre-conditioned (with HPLC-grade methanol and water, both Fisher Chemicals) $1 \mathrm{~g}$ Oasis HLB cartridges (60 $\mu \mathrm{m}$ particle size; Waters, Manchester, UK). The residue was then cleaned up using DSC-NH2 cartridges according to Flores et al. (2008). Full details of the SPE method can be found in the Supplementary Information. Subsequent measurement of E1, E2, EE2 concentrations was performed via ultra high-performance liquid chromatography tandem mass spectrometry (UHPLC-MS/MS) using a Waters Acquity UHPLC system coupled to a Quattro Premier triple quadrupole mass spectrometer from Micromass (Waters, Manchester, UK). The method detection limits (MDL) for E1, E2 and EE2 were $0.2 \mathrm{ng} / \mathrm{L}, 0.4 \mathrm{ng} / \mathrm{L}$ and $0.5 \mathrm{ng} / \mathrm{L}$, respectively. The method quantification limits (MQL) for E1, E2 and EE2 were $0.6 \mathrm{ng} / \mathrm{L}, 1.2 \mathrm{ng} / \mathrm{L}$ and $1.5 \mathrm{ng} / \mathrm{L}$, respectively. Details of the LC-MS method can be found in the Supplementary Information. All positive controls (EE2) and controls were treated and extracted under the same conditions.

\subsection{Estimation of the relative oestrogenic potencies of the WWTW effluents tested} (based on the measurements of E1, E2, and EE2)

A ratio of relative potencies of 1:0.75:40 for E2:E1:EE2 were used to calculate the equivalent concentrations of E2 (EEQs) of the WwTW effluents for use in comparing the total steroidal oestrogenic content with responses for $g f p$ and $v t g$ induction levels of their respective mRNA in the exposed ERE-GFP zebrafish. These relative oestrogenic potencies were chosen based on information in the literature for the 
induction of VTG in cyprinid fish in vivo, including zebrafish (Jobling et al., 2006; Van den Belt et al., 2004). This toxic equivalency approach is recommended for assessing the risk of oestrogenic chemical mixtures, such as wastewater effluent, and is based on the assumption that the combined effects of endogenous oestrogens are additive in their effects (Thorpe et al., 2006).

\subsection{Experimental Exposures}

ERE-GFP zebrafish embryos ( $n=50$ per treatment $\times 3$ replicates in $400 \mathrm{ml}$ sterile glass dishes) were exposed from fertilisation to 96 hours post-fertilisation (hpf) to one of the following treatments: a dilution water control, a reference oestrogen positive control (EE2, at nominal concentration of $10 \mathrm{ng} / \mathrm{L}$ ) or a WwTW effluent at either $100 \%$ or diluted to $50 \%$ with embryo culture water (prepared according to the ISO-7346/3 guidelines (ISO, 1996). Each treatment was performed in triplicate. Stock solutions of EE2 ( $\geq 98 \%$ purity, purchased from Sigma, Poole, UK) were prepared in acetone (10 $\mathrm{mg} / \mathrm{L})$ and stored in a dark cold-room $\left(4^{\circ} \mathrm{C}\right)$ to minimise the risk of degradation. Solvent free working solutions were prepared in embryo culture water the day prior to use, by pipetting the required amount of stock solution into a glass bottle and evaporating the solvent away under a stream of nitrogen. In the embryo cultures, half of the treatment medium was replaced every $24 \mathrm{hr}$ (with freshly collected effluent) and all treatments were gently aerated using a glass pipet connected to tubing fed through each dish lid to ensure that the dissolved oxygen concentration remained greater than $80 \%$ of the air saturation value. 


\subsection{Fish sampling and analysis of phenotypic endpoints}

All animal use protocols were carried out ethically in accordance with U.K. Home Office guidelines (Animals (Scientific Procedures) Act 1986). Fish were sacrificed by terminal anaesthesia with benzocaine ( $0.5 \mathrm{~g} / \mathrm{L}$; ethyl-p-aminobenzoate; Sigma). Survival rates were assessed for each treatment every $24 \mathrm{hr}$ (see supplementary information Table S1). All surviving embryos in control groups across all experiments hatched by $72 \mathrm{hpf}$, so this was subsequently used to determine hatching rate (success) in other treatments groups. Subsequently, three pooled sets of embryos were sampled at $96 \mathrm{hpf}$ and examined for GFP expression using Western blot analysis ( $\mathrm{n}=30$ fish per treatment), for $v t g$ and gfp mRNA expression $(\mathrm{n}=45$ fish per treatment).

\subsection{Image analysis}

Using fluorescence microscopy (Zeiss Axio Observer.Z1; Zeiss, Cambridge, UK), GFP was measured in exposed zebrafish at 24, 48, 72 and $96 \mathrm{hpf}(\mathrm{n}=15 \mathrm{per}$ treatment). GFP was visualised using the same parameters with a 10x objective, employing the Axiovision digital software programme for the production of images. Exposure times employed were kept consistent and were dependent on the tissue studied (due to the varying levels of fluorescence intensity seen in the different target tissues; $50 \mathrm{~ms}$ for head region, $20 \mathrm{~ms}$ for mid trunk region, and $400 \mathrm{~ms}$ for tail section). Prior to live imaging all fish were anesthetised with $0.4 \%$ tricaine, mounted in $4 \%$ methylcellulose in a glass-bottom dish $(35 \mathrm{~mm})$ and oriented in dorsal, ventral and lateral views. All images were aligned, and the contrast adjusted using Adobe Photoshop CS4 (Adobe Systems, San Jose, CA, USA) keeping the same intensity for all samples. 


\subsection{Quantification of GFP (EGFP) using image analysis}

GFP in the individual tissues was quantified using Image $\mathrm{J}^{\mathrm{TM}}$ software (http://rsb.info.nih.gov/ij/). For each image, tissues of interest were masked (outlined) manually to provide a specific quantifiable region of interest (ROI). The mean pixel intensity value from the $\mathrm{ROI}$ was then used as a means of quantifying the fluorescence response, and this was applied in a consistent manner across all individuals analysed. Background was subtracted using the ImageJ rolling ball algorithm which removes any spatial variations of the background intensities as described by Sternberg (1983). For fluorescence quantification in the somites, three random measurements were taken employing a plug-in Python macro. GFP expression values are presented as a fold-increase in GFP above that in unexposed controls.

\subsection{Quantification of GFP (EGFP) using Western blot analysis}

Fish were sampled at $96 \mathrm{hpf}$ to quantify whole body GFP using Western blot analysis, according to the protocol described previously (Lee et al., 2012). Briefly, 10 embryos were dissolved in reduced $2 \times$ lithium dodecyl sulfate sample buffer (Invitrogen, Carlsbad, CA, USA), incubated at $70^{\circ} \mathrm{C}$ for 15 mins and then homogenised using a hand homogenizer. Samples were then centrifuged, applied to electrophoresis using NuPAGE NOVEX 4-12\% Bis-Tris gel (Invitrogen) and the separated proteins transferred onto a nitrocellulose membrane. This membrane was then incubated with blocking solution ( $5 \%$ skimmed milk in $1 \times$ phosphate-buffered saline $+0.1 \%$ Tween 20 (PBSTw), washed with ultrapure water $\left(\mathrm{ddH}_{2} \mathrm{O}\right)$ and incubated overnight at $4{ }^{\circ} \mathrm{C}$ with 
primary rabbit anti-GFP antibody (1:2,500) (AMS Biotechonology, Abingdon, UK).

Subsequently, the membrane was washed with $1 \times$ PBSTw, incubated with the secondary antibody (horseradish peroxidase-conjugated goat anti-rabbit IgG $(1: 2,000)$; Invitrogen) and then washed with 1× PBSTw. For GFP detection, western blotting luminol reagent (Thermo Scientific) was used. The signal strength of the GFP and alpha tubulin bands were evaluated with Image $\mathrm{J}$ software (http://rsbweb.nih.gov/ij/) and the GFP signal standardised to the intensity of alpha tubulin (used as loading control) and shown as a fold increase in GFP levels in exposed embryos above that in unexposed embryos.

\subsection{Quantification of the relative transcript levels of gfp and vtg in whole embryo-} larvae using $R T-q P C R$

\subsubsection{RNA extraction and cDNA synthesis}

Samples for measurement of whole body $v t g$ and $g f p$ mRNA were immediately snap-frozen in liquid nitrogen upon collection and stored at $-80{ }^{\circ} \mathrm{C}$ until use. Total RNA was extracted from all samples using Trizol Reagent (Sigma), according to the manufacturer's instructions. The amount of RNA was quantified using a NanoDrop 1000 spectrophotometer and RNA purity determined through the measurement of the A260/A280 and A260/A230 ratios, respectively. Reverse transcription was subsequently carried out by incubating $1 \mu \mathrm{g} R Q 1$ DNase treated (Promega, Southampton, UK) total RNA with $5 \mathrm{mM}$ random hexamers (Eurofins MWG Operon. Ebersberg, Germany) $10 \mathrm{mM}$ dNTPs and $1 \mu \mathrm{l}$ MMLV-Reverse transcriptase (Promega) in the appropriate buffer, following the manufacturer's instructions. 


\subsubsection{Real-time quantitative PCR}

RT-qPCR was carried out on cDNA samples for each treatment group and sampling point for selected target genes with the iCycler iQ Real-time Detection System (Bio-Rad Laboratories Inc., CA, USA). Gene-specific primer sequences for vtg and gfp were designed with Beacon Designer 7.2 software (Premier Biosoft International, Palo Alto, USA) and obtained from Eurofins MWG Operon. In brief, primer pairs were optimised for annealing temperature (Ta), specificity confirmed by melt curve analysis, and the detection range, linearity and amplification efficiency (E) established using serial dilutions of zebrafish cDNA. The primer sequences, PCR product sizes, annealing temperatures and PCR efficiencies for each primer pair are shown in the supplementary information (Table S2). RT-qPCR was carried out using iTaq Universal SYBR Green Supermix (Bio-Rad), with an initial activation step of 95 ${ }^{\circ} \mathrm{C}$ for 15 min followed by 40 cycles of denaturation $\left(95^{\circ} \mathrm{C}, 10 \mathrm{~s}\right)$ and annealing (appropriate Ta, $45 \mathrm{~s}$ ) and final melt curve analysis. Expression levels of ribosomal protein L8 ( $r p / 8$ ) were used as a 'housekeeping' gene to normalise the expression of other genes and determine efficiency-corrected relative expression levels, as described previously (Filby and Tyler, 2005). All samples were analysed in triplicates and a template-minus negative control was run on each plate to verify the absence of DNA contamination.

\subsection{Statistical analysis}

In all cases, data were checked for normality using the D'Agostino-Pearson test and for homogeneity of variance using Bartlett's or Levene's test prior to statistical analysis. Data meeting these criteria were analysed using parametric tests, e.g. analysis of variance (ANOVA) procedures, whilst data that did not conform to 
normality were subject to nonparametric tests, e.g. Kruskal-Wallis. Post hoc analysis was performed against controls using the Dunnett's test and with the Tukey test for between-treatment comparisons. Data were transformed, where necessary, using log10. Any significant differences from expected sex ratios or stages of gonadal development were tested using the chi-square test. The relationship between levels of gfp vs vtg expression were measured using Pearson's correlation test. All statistical analyses were run in GraphPad Prism 7 (GraphPad Software, Inc., San Diego, USA). Statistical significance was accepted as $p<0.05$ for all comparisons and values are quoted as mean values and ranges as standard error (SE). To calculate monthly mean estrogen concentrations, concentrations that were over the limits of detection $(\geq$ $M D L)$ but below the limits of quantification (<MQL) were assigned the MDL value. Concentrations below the MDL were considered to be zero (David et al., 2018).

\section{Results}

3.1 Measured concentrations of major steroidal oestrogens in the test effluents

Analytical measurements for E1, E2 and EE2 (the three principal oestrogens occurring in WwTW effluent) were used to characterise the steroidal oestrogenic content of the different effluents. Measured concentrations of E1 and E2 found in all three WwTW effluents varied across the different collection time-points (Table 1). Except for one occasion, the synthetic oestrogen, EE2 was measured $<$ MDL $(0.5$ $\mathrm{ng} / \mathrm{L})$ in all effluent samples.

For WwTW1, concentrations of E1 in the four composite samples collected over the course of 4 days ranged between 14.0 and $18.41 \mathrm{ng} / \mathrm{L}$ during March 2014 (mean $16.7 \pm 1.1 \mathrm{ng} / \mathrm{L}$ ), lower in October 2014 (between 3.9 and $5.0 \mathrm{ng} / \mathrm{L}$; mean $4.4 \pm 0.2$ ng/L) and were considerably lower during July 2014 (between < MDL and 1.3 ng/L; 
mean $0.6 \pm 0.24 \mathrm{ng} / \mathrm{L}$ ) and January 2015 (between < MDL and $0.6 \mathrm{ng} / \mathrm{L}$; mean $0.6 \pm$ $0.04 \mathrm{ng} / \mathrm{L}$ ). E2 concentrations ranged between $<\mathrm{MDL}$ and $2.4 \mathrm{ng} / \mathrm{L}$ (annual mean 0.16 $\pm 0.11 \mathrm{ng} / \mathrm{L}$ ) over the entire exposure period with the highest recorded levels seen during July $2014(1.6 \pm 0.42 \mathrm{ng} / \mathrm{L})$. The level of total oestrogenic activity for this WwTW effluent ranged between $0.6 \mathrm{ng} / \mathrm{L}$ to $13.7 \mathrm{ng} / \mathrm{L}$ EEQs.

The WwTW2 effluent was the most strongly oestrogenic of the effluents tested, where concentrations of E1 ranged between 23.4 and $56.9 \mathrm{ng} / \mathrm{L}$ during January 2015 (mean $36.7 \pm 6.05 \mathrm{ng} / \mathrm{L}$ ) and were at their lowest (between $<\mathrm{MDL}$ and $2.1 \mathrm{ng} / \mathrm{L}$ ) during October 2014 (mean $1.1 \pm 0.42$ ng/L). E2 concentrations ranged between < MDL and $4.0 \mathrm{ng} / \mathrm{L}$ (annual mean $2.6 \pm 0.0 .15 \mathrm{ng} / \mathrm{L}$ ) over the entire exposure period with the highest recorded levels seen during March 2014 (4.0 $\pm 0.09 \mathrm{ng} / \mathrm{L})$. Levels of total oestrogenic activity measured at this site ranged between $1.1 \mathrm{ng} / \mathrm{L}$ and $46.8 \mathrm{ng} / \mathrm{L}$ EEQs.

For WwTW3, measured concentrations of E1 from the different consignments of effluent collected ranged between 7.8 and $14.5 \mathrm{ng} / \mathrm{L}$ during April 2015 (mean $11.4 \pm$ $1.22 \mathrm{ng} / \mathrm{L}$ ) and were at their lowest, at between < MDL and $4.7 \mathrm{ng} / \mathrm{L}$, during July 2015 (mean $1.9 \pm 0.89 \mathrm{ng} / \mathrm{L}$ ). E2 concentrations varied between 0.4 and $4.6 \mathrm{ng} / \mathrm{L}$ (mean 2.4 $\pm 1.08 \mathrm{ng} / \mathrm{L}$ ) during April 2015, and were lowest, at < MDL during October 2014 and January 2015. Levels of total oestrogenic activity measured at WwTW3 ranged between $1.6 \mathrm{ng} / \mathrm{L}$ and $11.0 \mathrm{ng} / \mathrm{L} \mathrm{EEQs.}$

EE2, E2 and E1 were below the minimum detection level in all control water samples. Chemical analysis of the positive control EE2, showed measured concentrations ranging from between $70-130 \%$ of the nominal test concentration (mean value, $7.8 \pm 0.03 \mathrm{ng} / \mathrm{L}$ ). 


\subsection{Responses of the ERE-GFP zebrafish to the WwTW effluent exposures}

\subsubsection{Embryo_hatching rates (at $72 \mathrm{hpf}$ ) and survival rates (at $96 \mathrm{hpf}$ )}

All surviving embryos in control groups across all experiments hatched by $72 \mathrm{hpf}$ and this was subsequently used to determine hatching success in other treatments groups. Exposures to EE2 alone resulted in a reduced hatching rate in all experiments conducted (with reduction between 60 and 74\%; Fig. 1A-Cii). For the WwTW1 effluent, hatching success for embryos exposed to $100 \%$ effluent was reduced $(p<0.001)$ at all sampling periods (Fig. 1Aii) and there were also differences in the hatching rate for the 50\% effluent (Fig. 1Aii) during March $2014(56 / 90=62 \%, p<0.001)$ and January $2015(58 / 90=64 \%, p<0.01)$. In the WwTW2 effluent (both 50\% and/or 100\%) hatching onset was advanced, seen at $48 \mathrm{hpf}$, at all sampling periods (data not shown). Hatching success for this effluent was reduced in the full-strength effluent at all sampling times (ranging between $28 \%$ and $70 \%$, Fig. 1Bii) and in the $50 \%$ effluent (Fig. 1Bii) during March 2014 and January 2015 (35/90 = 39\%, $p<0.001$ and 56/90 = $62 \%, p<0.001$, respectively), with an apparent reduction in October 2014 (although this was not statistically significant). In the WwTW3 effluent (50\% and $100 \%$ effluent), hatching success was reduced at all time points (Fig. 1Cii).

There were no effects on survival for exposures to EE2 (10 ng/ $\mathrm{L}$ nominal; Fig. 1ACi). For effluent exposures, no effects on survival were seen for exposures to the WwTW1 or WwTW3 (Fig. 1Ai, 1Ci), whereas a lower survival rate was observed for embryos exposed to $100 \%$ WwTW2 effluent in March $2014(45 / 90=50 \%, p<0.001)$ and January $2015(59 / 90=66 \%, p<0.05)(F i g .1 \mathrm{Bi})$. 


\subsubsection{GFP expression}

\subsubsection{Tissue response patterns at $96 \mathrm{hpf}$}

In some of the control ERE-TG larvae there was a low-level signal of endogenous GFP in the heart ( $49 \%$ of all the larvae) and in the otic vesicle ( $56 \%$ of the larvae), but in most larvae no GFP was observed (Fig. 2A). In embryo larvae exposed to EE2, GFP was observed in the liver, heart, somites, otic vesicle, fins and forebrain (Fig. 2B). Exposure to full-strength (100\%) effluent from the three WwTW induced different tissue patterns of the GFP signal (Fig. 2C-E). There was also variation in the GFP detected in body tissues at any one study site for the different effluent collections. In embryos exposed to full-strength WwTW1 effluent, GFP was observed in the liver, heart and somites in March 2014 and heart only at all other sampling-points (Figs 2C \& S1C-F) and in the $50 \%$ effluent (data not shown).

In embryos exposed to full-strength WwTW2 effluent, GFP was observed in the neuromasts and in the liver, heart and somites in January 2015 (Figs. 2D\&S1J), in the heart and somites in March 2014 (Fig. S1G) and in the heart only in July and October 2014 (Figs. S1H\&I). In 50\% effluent, GFP expression was observed in the liver and somites in January 2015 and in the heart at all other sampling points (data not shown).

For the full-strength WwTW3 effluent, GFP was observed in the heart and somites during January 2015 (Fig. S1L), April 2015 (Fig. S1M) and July 2015 (Fig. 2E) and in the heart only at all other sampling-points (Figs. S1K\&N) and 50\% effluent exposures. No specific GFP was detected in the liver for this effluent exposures. A time-related analysis of the GFP induction (percentage of embryos with detectable GFP at time points $24 \mathrm{hpf}, 48 \mathrm{hpf}, 72 \mathrm{hpf}$ and $96 \mathrm{hpf}$ ) in the different tissues is shown in the supplementary information (Table S3). 


\subsubsection{Tissue GFP quantified at 96 hpf via image analysis}

Exposure to $10 \mathrm{ng} / \mathrm{L}$ EE2 in all cases resulted in fluorescence induction in the liver, heart and somites, compared with untreated controls, with average fold-increases of 82 in the liver, between no response and 38 in the heart, and between no response and 50 in the somites (Fig. 3A-C). For the WwTW1 effluent, GFP induction was seen in the liver in 100\% effluent in March 2014 (16.4-fold, $p<0.001$; Fig. 3Ai). In the heart, there was a GFP induction in the 50\% and 100\% effluent treatments during March 2014 (8.4-fold, $p<0.05$ and 19.5-fold, $p<0.001$ ) and in the $100 \%$ effluent treatment in October 2014 (14.5-fold, $p<0.01$; Fig. 3Aii). There was also GFP induction in the somites for exposure to full-strength effluent in March 2014 (6.07-fold, $p<0.05$; Fig. 3 Aiii).

For the WwTW2 effluent, induction of GFP occurred in the liver in January 2015 for both the $50 \%$ and $100 \%$ effluent exposures (13.3-fold, $p<0.01$ and 61.7 -fold, $p<$ 0.001, respectively Fig. 3Bi) and in the heart for both effluent exposure concentrations at all sampling times (50\% effluent - ranging from 10.4 to 13.5 -fold; $p$ values between $<0.01$ and $0.05 ; 100 \%$ effluent - ranging from 11.3 to 19.4 -fold; $p$ values $<0.01$; Fig. 3Bii). Elevated GFP in the somites occurred in this effluent in January 2015 (both $50 \% ; p<0.01$ and $100 \%$ exposures; $p<0.001)$ and during March $2014(100 \%$ effluent $p<0.05$; Fig. 3Biii).

For the WwTW3 effluent exposures, GFP induction occurred in the heart at all time points with the exception of October 2014 for both effluent exposures (50\% effluent ranging from 11.2 to 15.6 -fold; $p$ values between $<0.05$ and $0.01 ; 100 \%$ effluent ranging from 10.2 to 20.7 -fold; $p$ values between $<0.05$ and 0.001 ; Fig. 3Bii; Fig. 3Cii). GFP in the somites was elevated in January and April 2015 (4.9 and 5.6-fold respectively; $p<0.05$ ) in 100\% effluent exposures only (Fig. 3Ciii). 
3.2.2.3 Whole-body GFP responses quantified via Western blotting after $96 \mathrm{hpf}$

Exposure to EE2 (10 $\mathrm{ng} / \mathrm{L})$ resulted in whole body elevated GFP for all exposures conducted, compared with untreated controls (39-42-fold-increase, $p<0.01$, Fig. 4). Elevated whole body GFP for the WwTW1 effluent occurred only for the exposure to 50\% and full-strength effluent in March 2014, where there was an up to 18-fold induction (Fig. 4A). For exposures to the WwTW2 effluent, GFP was elevated in the full-strength effluent in March 2014 (Fig. 4B; 6-fold increase compared with untreated controls) and both 50\% and 100\% effluent exposures in January 2015 (Fig. 4; 9-fold increase, $p<0.05$, and 19-fold increase, $p<0.05$, respectively). For the WwTW3 effluent, GFP was elevated only for the exposure to full-strength effluent in April 2015 (10-fold increase compared with controls, $p<0.05$, Fig. 4C).

\subsubsection{Quantification of whole embryo vtg mRNA and gfp mRNA}

Exposure to EE2 $(10 \mathrm{ng} / \mathrm{L})$ resulted in between a 7 - and 11 -fold-higher relative transcript levels of $g f p$ and between 40 and 50 -fold higher relative transcript levels of $v t g$, respectively $(p<0.01$, Fig. 5A-C). In the WwTW1 effluent exposures, gfp mRNA levels appeared to be higher (approximately 3-fold induction) in embryos exposed to full-strength effluent during March 2014, but this was not statistically significant (Fig. 5Ai). A higher level of vtg mRNA level occurred only in embryos exposed to fullstrength WwTW1 effluent during March 2014 (8-fold higher compared to controls, $p<$ 0.01 , Fig. 5Aii), and this was higher also when compared with levels of vtg mRNA levels measured in July 2014, October 2014 and January 2015 ( $p<0.05$ Fig. 5Aii). gfp mRNA expression in the WwTW2 effluent exposures was higher compared with controls for the full-strength effluent in January 2015 (a 5-fold induction; $p<0.05$, Fig. 5Bi) and compared also with the full-strength effluent in July and October 2014 ( $p<$ 
0.05, Fig. 5Bi). In the full-strength WwTW2 effluent, the vtg mRNA level in embryo larvae was higher in both March 2014 and January 2015 (3-fold and 22-fold induction, respectively, both $p<0.01$; Fig. 5Bii) compared with controls. In the full-strength effluent exposures, vtg mRNA levels were higher in January 2015 compared with all other time-points ( $p<0.05$, Fig. 5Bii). For the WwTW3 effluent, the only indications of a higher amount of gfp mRNA expression (approximately 2-fold) was for the fullstrength effluent exposures in January and April 2015, but these were not statistically significant (Fig. 5Ci). vtg mRNA levels were higher in embryos following exposure to full-strength effluent during April 2015 only compared with controls (5-fold higher, $p<$ 0.05, Fig. 5Cii) and compared with full strength effluent for the October 2014 and January and July 2015 exposures ( $p<0.05$, Fig. 5Cii).

The magnitude of responses for vtg induction was higher compared to gfp in both the EE2 (Fig 6A) and wastewater effluent exposures (Fig. 6B). For the data combined there was a positive correlation between the levels of gfp expression and the levels of $v t g$ expression for the EE2 exposure $\left(r^{2}=0.5 ; p<0.01 ; n=15\right.$ fish per treatment) whereas a very weak relationship was found for the effluent exposures $\left(r^{2}=0.2, p<\right.$ $0.05 ; n=15$ fish per treatment) (Fig 6).

\section{Discussion}

\subsection{Temporal variation in effluent oestrogenicity}

Measured concentrations of the steroidal oestrogens E1 and E2 (and ratios between them) in the three WwTW effluents varied by more than 3-fold over the 12 month period supporting previous reports on temporal variation in the oestrogenic content of wastewater effluents (Vajda et al., 2008; Zhou et al., 2012). Relatively high 
levels of $\mathrm{E} 1$, in comparison with $\mathrm{E} 2$, were measured at all three treatment works (here ranging from $0.03-36.7 \mathrm{ng} / \mathrm{L}$ ), and were analogous with those that have reported previously in WwTW effluents (Furtula et al., 2012; Williams et al., 2012). The higher levels of E1 are explained by a relatively slower degradation rate of E1 and by the oxidation of E2 to $\mathrm{E} 1$ that occurs during wastewater treatment processes (Combalbert and Hernandez-Raquet, 2010; Desmiarti and Li, 2013). There was no obvious temporal variability in the synthetic oestrogen EE2 at any of the studied treatment works, with measured concentrations almost consistently below the method detection limit $(0.5 \mathrm{ng} / \mathrm{L})$; these levels also compare favourably with other studies internationally (e.g. Cui et al., 2006; Hannah et al., 2009).

Various studies have shown that higher temperatures in the summer months can enhance the efficiency of biological treatment processes in removing steroidal oestrogens, due to increased growth (and hence biodegradation) rates of microbial communities, with the reverse occurring during the winter (Jin et al., 2008; Martinović et al., 2008), but we did not find this as a consistent pattern for the different steroid oestrogens across the different WwTWs. The efficiency of a WwTW in removing both natural and synthetic oestrogens, however, is influenced by many different factors including temperature and rainfall, as well as microbial content, all of which can vary seasonally. It is also the case that high temperatures, in combination with lower rainfall, can result in microbial communities operating at a much lower efficiency rate (Cruikshank and Gilles, 2007).

We found lower levels of steroidal oestrogens in WwTW effluents were associated with higher rainfall levels when they occurred during the summer months. Higher levels of rainfall (and hence greater dilution) have been shown previously to lead to lower oestrogenic content in WwTW effluents in other studies (Diniz et al., 2005; 
Phillips et al., 2012). Contrasting with this however, high levels of rainfall (and hence higher flow rates of influent entering a WwTW) can also result in a reduced total Hydraulic Retention Time (HRT), thus leading to reduced treatment efficiencies (Kumar et al., 2015; Phillips et al., 2012). This may account for the high level of E1 observed at WwTW2 during January 2015 (i.e. $46.8 \mathrm{ng} / \mathrm{L}$ EEQs) when there was a period of very high rainfall. This WwTW also had a relatively short HRT (only $2.5 \mathrm{hrs}$ ) compared with WwTW1 (18 hrs) and WwTW3 (12 hrs) and a longer HRT is generally associated with a more efficient removal of steroidal oestrogens (Ejhed et al., 2018; Huang et al., 2008). Other factors that may have contributed to the variability in the oestrogenic activity in the different WwTW effluents include fluctuations in the input of organic matter (quantified by biological oxygen demand [BOD] and total suspended solids [TSS]), that affect the binding of environmental oestrogens and thus their bioavailability for uptake.

Whilst seasonal influences of temperature and rainfall are important factors in determining levels of steroidal oestrogens in wastewater effluent, the method of treatment employed at a WWTW can be extremely influential. Our study suggests that WwTW1, with an Activated Sludge (AS) secondary treatment process, was more efficient at removing steroidal oestrogens compared with the Biological Filter (BF) processes in place at the other WwTWs which concurrs with other observations on removal efficiency between the two processes (Gabet-Giraud et al., 2010; Johnson et al., 2007).

Chemical make-up of the wastewater influent to a treatment works can also affect the subsequent effluent quality. In this study, the majority of wastewater entering all three WwTWs was domestic in origin, with only a small percentage of industrial input (between 3.3 to $7.1 \%$ ). We found no link between the total population equivalent size 
of a particular WwTW and the amount of oestrogenic activity in the resulting effluent. Some of the seasonal variations in the oestrogen content of the effluents at WwTW1 and WwTW2 could be due to changes in the seasonal resident population (e.g. due to student enrolment for local universities) and which may contribute to the higher oestrogenic content observed at both works during March 2013 and January 2014. The variability in the oestrogenic content of the WwTW effluents emphasises the importance of avoiding extrapolations from single time point analysis.

\subsection{Responses of the ERE-GFP zebrafish embryo-larvae to the effluent treatments}

\subsubsection{Survivorship and Hatching}

Exposure to EE2 (at $10 \mathrm{ng} / \mathrm{L}$ ) had no effects on survivorship supporting the findings from other studies (Jackson and Klerks, 2019; Schäfers et al., 2007). The enhanced mortality seen at $96 \mathrm{hpf}$ for exposures to full strength WwTW2 effluent during March 2014 and January 2015 corresponded with a high oestrogenic potency but this is unlikely responsible for these mortalities. Rather this is likely due to some other physio-chemical features of the effluent at these times, which might include the presence of toxic contaminants, or elevated ammonia levels due to poor treatment efficiency. At these sampling times, levels of both chloride and ammonia (up to 4000 and $40 \mathrm{mg} / \mathrm{L}$, respectively) were known to be elevated caused by saline infiltration from the local sewerage system. Reduced hatching rates in the EE2 and effluent exposures are in accordance with that seen in published studies (Smolders et al., 2002; Versonnen and Janssen, 2004). The mechanism(s) for this effect are not known but they may include chemicals in the effluent affecting hatching enzyme systems as had been reported for selected chemicals previously (De la Paz et al., 2017; Trikić et al., 2011). 


\subsubsection{GFP and VTG expression}

Exposure to EE2 induced GFP responses in the ERE-GFP transgenic zebrafish embryo larvae in a very wide range of tissues, including heart, liver, somite muscle and forebrain, in agreement with other studies (Green et al., 2016; Lee et al., 2012; Moreman et al., 2017). The wide range of target tissues for EE2 together with its high potency and its tendency to bio-concentrate in body tissues in fish (Fenlon et al., 2010; Yang et al., 2014) serve to re-enforce the key role this synthetic oestrogens likely plays in the feminised responses seen in wild fish populations in UK rivers (Tyler and Jobling, 2008).

Induction of GFP in the ERE-GFP transgenic zebrafish exposed to the WwTW effluents were seen consistently in the heart, liver, muscle somites and otic vesicle. Responses were seen also in the forebrain and neuromasts for exposure to the WwTW2 effluent. All of these tissues have been shown previously to be responsive to steroidal oestrogens but also to other environmental oestrogens including 4nonylphenol, and various bisphenolic compounds (Green et al., 2016; Lee et al., 2012; Moreman et al., 2017), that are known to occur commonly in WwTW effluents (Hu et al., 2019; Klečka et al., 2010). In the WwTW2 effluent in January 2015, the strong GFP induction in the liver was most likely a consequence of exposure to high level of E2 at this time. In contrast, in the WwTW3 effluent exposure in April 2015, there was little or no GFP expression in the liver, but induction was found in the somites, suggesting a response mediated by a non-steroidal oestrogen, with possible chemical candidates for this such as nonylphenol or bisphenolic compounds. The variation in tissue responses indicate the potential for differing health effects between different WwTW effluents and even for a single effluent over different times in the year. The differences in tissue specificities for the GFP induction may be due to differences in 
tissue expression and interactions with the three oestrogen receptor subtypes and other related receptors that can form heterodimers with ERs (Gorelick et al., 2014; Tingaud-Sequeira et al., 2004). The high sensitivity of the heart to both EE2 and oestrogens contained in WwTW effluents is consistent with responses seen in another oestrogen responsive transgenic zebrafish line (Gorelick et al., 2014) and serves to further illustrate the need for further studies on possible health outcomes in fish for chronic environmental exposures given the known crucial role of oestrogenic signalling in heart development (Celeghin et al., 2011; Pugach et al., 2016) and findings for harmful effects on heart development in fish (Brown et al., 2019; e.g. Moreman et al., 2017).

$v \operatorname{tg}$ mRNA levels in the ERE-GFP fish mirrored the concentrations of steroidal oestrogens measured for exposure all three WWTW effluents, supporting steroidal oestrogens being largely responsible for vtg induction in fish exposed to wastewater effluents; E1 and E2, together with EE2, often make up $80 \%$ of a WwTW effluent oestrogenic activity (Desbrow et al., 1998; Rodgers-Gray et al., 2000). There was a positive correlation between gip mRNA levels and vtg mRNA levels for the EE2 exposures but this was less apparent in the case of WwTW effluent exposures. For the latter, this may be because the response for GFP (whole body) measures responses across many tissues and induction/effect mechanisms compared with that for VTG that occurs in the liver only. Direct comparison of whole embryo-larvale gfp mRNA expression with $v t g$ mRNA expression demonstrated that $v t g$ mRNA expression was more responsive in terms of the sensititvity threshold for induction and magnitude of response; the huge dynamic range for vtg mRNA induction (and its protein product of up to a million-fold; Tyler et al., 1996) is well established. 


\section{Conclusion}

This study demonstrates that the ERE-GFP transgenic zebrafish model can be applied to detect environmental oestrogens in wastewater effluent samples and exhibits tissue-specific effects similar to those seen for exposure to different individual environmental oestrogens. Differences in GFP tissue patterning (and of other biological endpoints) were found to be reflective of the varying concentrations of steroidal oestrogens found in the different wastewaters (both temporally and between treatment works), and illustrated the considerable dynamic nature of the oestrogenic potencies of the WwTW effluents. Currently, analytical chemistry is generally the method of choice in large and regular chemical monitoring campaigns but this approach largely ignores the combined effects of substances with the same or similar mode of action. The ERE-GFP transgenic zebrafish model, in contrast, provides an integrative measure for the effects of exposure to oestrogenic chemical mixtures (here, in wastewater effluents) and in turn provides a highly complementary approach with analytical chemistry for chemical monitoring. Whilst these results suggest that GFP induction is less sensitive as a detection method than VTG for detecting responses to oestrogen, the ERE-GFP zebrafish provides an integrative model system to help understand more fully the tissues targeted for more effective health effects analyses, and thus ecological risk assessment posed by wastewater effluents, specifically in respect of AOP frameworks.

Acknowledgements: Ruth Cooper was funded by a Biology and Biotechnology Research Council studentship (reference: BB/K501281/1). The project was further supported by the University of Exeter on grants to CRT. AD was supported by a Marie Curie Intra European Fellowship within the European Community Seventh Framework Programme ([FP7/2007-2013]) under grant agreement no.:302097. We thank the 
Aquatic Resources Centre technical team, at the University of Exeter, for their support with fish husbandry and exposure studies, and Dr Anke Lange for her support with the molecular work and in editing of the manuscript.

CRediT author statement: Ruth Cooper: Conceptualization, Investigation, Methodology, Formal analysis, Visualization, Writing - original draft. Arthur David: Methodology, Investigation, Formal analysis, Writing - Review \& Editing. Tetsuhiro Kudoh: Supervision, Providing the biosensor fish strain, Writing - Review \& Editing. Charles R. Tyler: Conceptualization, Supervision, Project administration, Funding acquisition, Writing - review \& editing.

Conflict of interest: The authors have no conflicts of interest.

\section{Declaration of interests}

$\bigotimes$ The authors declare that they have no known competing financial interests or personal relationships that could have appeared to influence the work reported in this paper.

$\square$ The authors declare the following financial interests/personal relationships which may be considered as potential competing interests:

\section{References}

Bahamonde, P.A., Fuzzen, M.L., Bennett, C.J., Tetreault, G.R., McMaster, M.E., Servos, M.R., Martyniuk, C.J., Munkittrick, K.R., 2015a. Whole organism responses and intersex severity in rainbow darter (Etheostoma caeruleum) following exposures to municipal wastewater in the Grand River basin, ON, Canada. Part A. Aquatic Toxicology 159, 290301. https://doi.org/10.1016/j.aquatox.2014.11.023

Bahamonde, P.A., McMaster, M.E., Servos, M.R., Martyniuk, C.J., Munkittrick, K.R., 2015b. Molecular pathways associated with the intersex condition in rainbow darter (Etheoytstoma caeruleum) following exposures to municipal wastewater in the Grand 
River basin, ON, Canada. Part B. Aquatic Toxicology 159, 302-316. https://doi.org/10.1016/j.aquatox.2014.11.022

Bakos, K., Kovacs, R., Balogh, E., Sipos, D.K., Reining, M., Gyomorei-Neuberger, O., Balazs, A., Kriszt, B., Bencsik, D., Csepeli, A., Gazsi, G., Hadzhiev, Y., Urbanyi, B., Mueller, F., Kovacs, B., Csenki, Z., 2019. Estrogen sensitive liver transgenic zebrafish (Danio rerio) line $(\operatorname{Tg}(\mathrm{vtg} 1: \mathrm{mCherry}))$ suitable for the direct detection of estrogenicity in environmental samples. Aquatic Toxicology 208, 157-167.

https://doi.org/https://doi.org/10.1016/j.aquatox.2019.01.008

Ben, W., Zhu, B., Yuan, X., Zhang, Y., Yang, M., Qiang, Z., 2018. Occurrence, removal and risk of organic micropollutants in wastewater treatment plants across China: Comparison of wastewater treatment processes. Water Research 130, 38-46. https://doi.org/https://doi.org/10.1016/j.watres.2017.11.057

Borgia, V.J.F., Thatheyus, A.J., Murugesan, A.G., Alexander, S.C.P., Geetha, I., 2018. Effects of effluent from electoplating industry on the immune response in the freshwater fish, Cyprinus carpio. Fish \& Shellfish Immunology 79, 86-92. https://doi.org/https://doi.org/10.1016/j.fsi.2018.05.010

Brown, A.R., Green, J.M., Moreman, J., Gunnarsson, L.M., Mourabit, S., Ball, J., Winter, M.J., Trznadel, M., Correia, A., Hacker, C., Perry, A., Wood, M.E., Hetheridge, M.J., Currie, R.A., Tyler, C.R., 2019. Cardiovascular effects and molecular mechanisms of Bisphenol A and its metabolite MBP in zebrafish. Environmental Science \& Technology 53, 463474. https://doi.org/10.1021/acs.est.8b04281

Cavallin, J.E., Jensen, K.M., Kahl, M.D., Villeneuve, D.L., Lee, K.E., Schroeder, A.L., Mayasich, J., Eid, E.P., Nelson, K.R., Milsk, R.Y., Blackwell, B.R., Berninger, J.P., LaLone, C.A., Blanksma, C., Jicha, T., Elonen, C., Johnson, R., Ankley, G.T., 2016. Pathway-based approaches for assessment of real-time exposure to an estrogenic wastewater treatment plant effluent on fathead minnow reproduction. Environmental Toxicology and Chemistry 35, 702-716. https://doi.org/https://doi.org/10.1002/etc.3228

Celeghin, A., Benato, F., Pikulkaew, S., Rabbane, M.G., Colombo, L., Dalla Valle, L., 2011. The knockdown of the maternal estrogen receptor 2a (esr2a) mRNA affects embryo transcript contents and larval development in zebrafish. General and Comparative Endocrinology 172, 120-129. https://doi.org/https://doi.org/10.1016/j.ygcen.2010.12.020

Combalbert, S., Hernandez-Raquet, G., 2010. Occurrence, fate, and biodegradation of estrogens in sewage and manure. Applied Microbiology and Biotechnology 86, 16711692. https://doi.org/10.1007/s00253-010-2547-x

Corcoran, E., Nellemann, C., Baker, E., Bos, R., Osborn, D., Savelli, H., 2010. Sick water?. The central role of wastewater management in sustainable development. A rapid response assessment. United Nations Environment Programme (UNEP), UN-HABITAT.

Cruikshank, C., Gilles, D., 2007. Temperature modeling and control for biological wastewater treatment design. Proceedings of the Water Environment Federation 2007/7, 120-132. https://doi.org/10.2175/193864707787781160

Cui, C.W., Ji, S.L., Ren, H.Y., 2006. Determination of steroid estrogens in wastewater treatment plant of a controceptives producing factory. Environmental Monitoring and Assessment 121, 409-419. https://doi.org/10.1007/s10661-005-9139-8

David, A., Lange, A., Tyler, C.R., Hill, E.M., 2018. Concentrating mixtures of neuroactive pharmaceuticals and altered neurotransmitter levels in the brain of fish exposed to a wastewater effluent. Science of the Total Environment 621, 782-790. https://doi.org/10.1016/j.scitotenv.2017.11.265

De la Paz, J.F., Beiza, N., Paredes-Zúñiga, S., Hoare, M.S., Allende, M.L., 2017. Triazole fungicides inhibit zebrafish hatching by blocking the secretory function of hatching gland cells. International Journal of Molecular Sciences 18, 710.

https://doi.org/10.3390/ijms 18040710 
Desbrow, C., Routledge, E.J., Brighty, G.C., Sumpter, J.P., Waldock, M., 1998. Identification of estrogenic chemicals in STW effluent. 1. Chemical fractionation and in vitro biological screening. Environmental Science \& Technology 32, 1549-1558. https://doi.org/10.1021/es9707973

Desmiarti, R., Li, F., 2013. Behavior of natural estrogens in activated sludge: biodegradation in semicontinuous reactor under aerobic, anaerobic and sequential anaerobic/aerobic conditions. Journal of Engineering and Technological Sciences 45, 113-124.

Diniz, M.S., Peres, I., Pihan, J.C., 2005. Comparative study of the estrogenic responses of mirror carp (Cyprinus carpio) exposed to treated municipal sewage effluent (Lisbon) during two periods in different seasons. Science of The Total Environment 349, 129-139. https://doi.org/https://doi.org/10.1016/j.scitotenv.2005.01.014

Ejhed, H., Fång, J., Hansen, K., Graae, L., Rahmberg, M., Magnér, J., Dorgeloh, E., Plaza, G., 2018. The effect of hydraulic retention time in onsite wastewater treatment and removal of pharmaceuticals, hormones and phenolic utility substances. Science of The Total Environment 618, 250-261. https://doi.org/https://doi.org/10.1016/j.scitotenv.2017.11.011

Fenlon, K.A., Johnson, A.C., Tyler, C.R., Hill, E.M., 2010. Gas-liquid chromatography-tandem mass spectrometry methodology for the quantitation of estrogenic contaminants in bile of fish exposed to wastewater treatment works effluents and from wild populations. Journal of Chromatography A 1217, 112-118. https://doi.org/10.1016/j.chroma.2009.10.063

Filby, A.L., Tyler, C.R., 2005. Molecular characterization of estrogen receptors $1,2 \mathrm{a}$, and $2 \mathrm{~b}$ and their Tissue and ontogenic expression profiles in Fathead minnow (Pimephales promelas). Biology of Reproduction 73, 648-662. https://doi.org/10.1095/biolreprod.105.039701

Furtula, V., Liu, J., Chambers, P., Osachoff, H., Kennedy, C., Harkness, J., 2012. Sewage treatment plants efficiencies in removal of sterols and sterol ratios as indicators of fecal contamination sources. Water, Air, and Soil Pollution 223, 1017-1031. https://doi.org/10.1007/s11270-011-0920-8

Gabet-Giraud, V., Miège, C., Choubert, J.M., Ruel, S.M., Coquery, M., 2010. Occurrence and removal of estrogens and beta blockers by various processes in wastewater treatment plants. Science of The Total Environment 408, 4257-4269. https://doi.org/https://doi.org/10.1016/j.scitotenv.2010.05.023

Gagné, F., Blaise, C., André, C., 2006. Occurrence of pharmaceutical products in a municipal effluent and toxicity to rainbow trout (Oncorhynchus mykiss) hepatocytes. Ecotoxicology and Environmental Safety 64, 329-336. https://doi.org/https://doi.org/10.1016/j.ecoenv.2005.04.004

Gauthier, P.T., Vijayan, M.M., 2020. Municipal wastewater effluent exposure disrupts early development, larval behavior, and stress response in zebrafish. Environmental Pollution 259, 113757. https://doi.org/https://doi.org/10.1016/j.envpol.2019.113757

Gorelick, D.A., Iwanowicz, L.R., Hung, A.L., Blazer, V.S., Halpern, M.E., 2014. Transgenic zebrafish reveal tissue-specific differences in estrogen signaling in response to environmental water samples. Environmental Health Perspectives 122, 356-362. https://doi.org/10.1289/ehp.1307329

Green, J.M., Lange, A., Scott, A., Trznadel, M., Wai, H.A., Takesono, A., Brown, A.R., Owen, S.F., Kudoh, T., Tyler, C.R., 2018. Early life exposure to ethinylestradiol enhances subsequent responses to environmental estrogens measured in a novel transgenic zebrafish. Scientific Reports 8, 2699. https://doi.org/10.1038/s41598-018-20922-z

Green, J.M., Metz, J., Lee, O., Trznadel, M., Takesono, A., Brown, A.R., Owen, S.F., Kudoh, T., Tyler, C.R., 2016. High-content and semi-automated quantification of responses to estrogenic chemicals using a novel translucent transgenic zebrafish. Environmental Science \& Technology 50, 6536-6545. https://doi.org/10.1021/acs.est.6b01243 
Hannah, R., D’Aco, V.J., Anderson, P.D., Buzby, M.E., Caldwell, D.J., Cunningham, V.L., Ericson, J.F., Johnson, A.C., Parke, N.J., Samuelian, J.H., Sumpter, J.P., 2009. Exposure assessment of $17 \alpha$-ethinylestradiol in surface waters of the United States and Europe. Environmental Toxicology and Chemistry 28, 2725-2732. https://doi.org/https://doi.org/10.1897/08-622.1

Hatch, E.E., Nelson, J.W., Stahlhut, R.W., Webster, T.F., 2010. Association of endocrine disruptors and obesity: perspectives from epidemiological studies. Internationall Journal of Andrology 33, 324-332. https://doi.org/10.1111/j.1365-2605.2009.01035.x

Hu, Y., Zhu, Q., Yan, X., Liao, C., Jiang, G., 2019. Occurrence, fate and risk assessment of BPA and its substituents in wastewater treatment plant: A review. Environmental Research 178, 108732. https://doi.org/https://doi.org/10.1016/j.envres.2019.108732

Huang, M., Li, Y., Gu, G., 2008. The effects of hydraulic retention time and sludge retention time on the fate of di-(2-ethylhexyl) phthalate in a laboratory-scale anaerobic-anoxicaerobic activated sludge system. Bioresource Technology 99, 8107-8111. https://doi.org/https://doi.org/10.1016/j.biortech.2008.03.031

ISO-International Organization for Standardization, 1996. Water Quality - Determination of the acute lethal toxicity of substances to a freshwater fish [Brachydanio rerio Hamiltonbuchanan (Teleostei, Cyprinidae)] - Part 1: Static method. Part 2: Semi-static method. Part 3: Flow-through Method.

Jackson, L.M., Klerks, P.L., 2019. Impact of long-term exposure to 17a-ethinylestradiol in the live-bearing fish Heterandria formosa. Archives of Environmental Contamination and Toxicology 77, 51-61. https://doi.org/10.1007/s00244-019-00600-5

Jeffries, K.M., Nelson, E.R., Jackson, L.J., Habibi, H.R., 2008. Basin-wide impacts of compounds with estrogen-like activity on longnose dace (Rhinichthys cataractae) in two prairie rivers of Alberta, Canada. Environmental Toxicology and Chemistry 27, 20422052. https://doi.org/10.1897/07-529.1

Jin, S., Yang, F., Liao, T., Hui, Y., Xu, Y., 2008. Seasonal variations of estrogenic compounds and their estrogenicities in influent and effluent from a municipal sewage treatment plant in China. Environmental Toxicology and Chemistry 27, 146-153. https://doi.org/https://doi.org/10,1897/07-072.1

Jobling, S., Williams, R., Johnson, A., Taylor, A., Gross-Sorokin, M., Nolan, M., Tyler, C.R., van Aerle, R., Santos, E., Brighty, G., 2006. Predicted exposures to steroid estrogens in U.K. rivers correlate with widespread sexual disruption in wild fish populations.

Environmental Health Perspectives 114, 32-39. https://doi.org/10.1289/ehp.8050

Johnson, A.C., Williams, R.J., Simpson, P., Kanda, R., 2007. What difference might sewage treatment performance make to endocrine disruption in rivers? Environmental Pollution 147, 194-202. https://doi.org/https://doi.org/10.1016/j.envpol.2006.08.032

Jørgensen, N., Joensen, U.N., Jensen, T.K., Jensen, M.B., Almstrup, K., Olesen, I.A., Juul, A., Andersson, A.-M., Carlsen, E., Petersen, J.H., Toppari, J., Skakkebæk, N.E., 2012. Human semen quality in the new millennium: a prospective cross-sectional populationbased study of 4867 men. BMJ Open 2, e000990. https://doi.org/10.1136/bmjopen-2012000990

Kidd, K.A., Blanchfield, P.J., Mills, K.H., Palace, V.P., Evans, R.E., Lazorchak, J.M., Flick, R.W., 2007. Collapse of a fish population after exposure to a synthetic estrogen. Proceedings of the National Academy of Sciences of the United States of America 104, 8897-8901. https://doi.org/10.1073/pnas.0609568104

Klečka, G.M., Naylor, C.G., Staples, C.A., Losey, B., 2010. Occurrence of nonylphenol ethoxylates and their metabolites in municipal wastewater treatment plants and receiving waters. Water Environment Research 82, 447-454.

https://doi.org/https://doi.org/10.2175/106143009X12529484815674 
Kumar, V., Nakada, N., Yamashita, N., Johnson, A.C., Tanaka, H., 2015. Influence of hydraulic retention time, sludge retention time, and ozonation on the removal of free and conjugated estrogens in Japanese activated sludge treatment plants. CLEAN - Soil, Air, Water 43, 1289-1294. https://doi.org/https://doi.org/10.1002/clen.201400498

Lacaze, E., Gauthier, C., André, C., Couture, P., Desrosiers, M., Cloutier, F., Gagné, F., 2017a. Municipal effluent exposures in fathead minnows during partial life cycle: Endocrine disruptive effects and impact on reproduction. Current Topics in Toxicology $13,31-45$.

Lacaze, E., Gauthier, C., Couture, P., André, C., Cloutier, F., Fournier, M., Gagné, F., 2017b. The effects of municipal effluents on oxidative stress, immunocompetence and DNA integrity in fathead minnow juveniles. Current Topics in Toxicology 13, 69-80.

Lang, I.A., Galloway, T.S., Scarlett, A., Henley, W.E., Depledge, M., Wallace, R.B., Melzer, D., 2008. Association of urinary bisphenol a concentration with medical disorders and laboratory abnormalities in adults. JAMA 300, 1303-1310. https://doi.org/10.1001/jama.300.11.1303

Lee, O., Takesono, A., Tada, M., Tyler, C.R., Kudoh, T., 2012. Biosensor zebrafish provide new insights into potential health effects of environmental estrogens. Environmental Health Perspectives 120, 990-996. https://doi.org/10.1289/ehp.1104433

Legler, J., van den Brink, C.E., Brouwer, A., Murk, A.J., van der Saag, P.T., Vethaak, A.D., van der Burg, B., 1999. Development of a stably transfected estrogen receptor-mediated luciferase reporter gene assay in the human T47D breast cancer cell line. Toxicological Sciences 48, 55-66. https://doi.org/10.1093/toxsci/48.1.55

Liney, K.E., Hagger, J.A., Tyler, C.R., Depledge, M.H., Galloway, T.S., Jobling, S., 2006. Health effects in fish of long-term exposure to effluents from wastewater treatment works. Environmental Health Perspectives 114, S81-S89.

Martinović, D., Denny, J.S., Schmieder, P.K., Ankley, G.T., Sorensen, P.W., 2008. Temporal variation in the estrogenicity of a sewage treatment plant effluent and its biological significance. Environmental Science \& Technology 42, 3421-3427. https://doi.org/10.1021/es0708013

McCallum, E.S., Krutzelmann, E., Brodin, T., Fick, J., Sundelin, A., Balshine, S., 2017. Exposure to wastewater effluent affects fish behaviour and tissue-specific uptake of pharmaceuticals. Science of The Total Environment 605-606, 578-588. https://doi.org/https://doi.org/10.1016/j.scitotenv.2017.06.073

Moreman, J., Lee, O., Trznadel, M., David, A., Kudoh, T., Tyler, C.R., 2017. Acute toxicity, teratogenic, and estrogenic effects of Bisphenol $A$ and its alternative replacements Bisphenol S, Bisphenol F, and Bisphenol AF in zebrafish embryo-larvae. Environmental Science \& Technology 51, 12796-12805. https://doi.org/10.1021/acs.est.7b03283

OECD, 2019. Test No. 203: Fish, Acute Toxicity Test, OECD Guidelines for the Testing of Chemicals, Section 2. OECD Publishing, Paris.

Phillips, P.J., Chalmers, A.T., Gray, J.L., Kolpin, D.W., Foreman, W.T., Wall, G.R., 2012. Combined sewer overflows: An environmental source of hormones and wastewater micropollutants. Environmental Science \& Technology 46, 5336-5343. https://doi.org/10.1021/es3001294

Pugach, E.K., Blenck, C.L., Dragavon, J.M., Langer, S.J., Leinwand, L.A., 2016. Estrogen receptor profiling and activity in cardiac myocytes. Molecular and Cellular Endocrinology 431, 62-70. https://doi.org/10.1016/j.mce.2016.05.004

Rocco, L., Frenzilli, G., Zito, G., Archimandritis, A., Peluso, C., Stingo, V., 2012. Genotoxic effects in fish induced by pharmacological agents present in the sewage of some Italian water-treatment plants. Environmental Toxicology 27, 18-25.

https://doi.org/https://doi.org/10.1002/tox.20607 
Rodgers-Gray, T.P., Jobling, S., Morris, S., Kelly, C., Kirby, S., Janbakhsh, A., Harries, J.E., Waldock, M.J., Sumpter, J.P., Tyler, C.R., 2000. Long-term temporal changes in the estrogenic composition of treated sewage effluent and its biological effects on fish. Environmental Science \& Technology 34, 1521-1528. https://doi.org/10.1021/es991059c

Routledge, E.J., Sumpter, J.P., 1996. Estrogenic activity of surfactants and some of their degradation products assessed using a recombinant yeast screen. Environmental Toxicology and Chemistry 15, 241-248.

https://doi.org/https://doi.org/10.1002/etc.5620150303

Sanchez, W., Sremski, W., Piccini, B., Palluel, O., Maillot-Maréchal, E., Betoulle, S., Jaffal, A., Aït-Aïssa, S., Brion, F., Thybaud, E., Hinfray, N., Porcher, J.-M., 2011. Adverse effects in wild fish living downstream from pharmaceutical manufacture discharges. Environment International 37, 1342-1348. https://doi.org/https://doi.org/10.1016/j.envint.2011.06.002

Schäfers, C., Teigeler, M., Wenzel, A., Maack, G., Fenske, M., Segner, H., 2007. Concentration- and time-dependent effects of the synthetic estrogen, 17aethinylestradiol, on reproductive capabilities of the zebrafish, Danio rerio. Journal of Toxicology and Environmental Health, Part A 70, 768-779. https://doi.org/10.1080/15287390701236470

Schwindt, A.R., Winkelman, D.L., Keteles, K., Murphy, M., Vajda, A.M., 2014. An environmental oestrogen disrupts fish population dynamics through direct and transgenerational effects on survival and fecundity. Journal of Applied Ecology 51, 582591. https://doi.org/10.1111/1365-2664.12237

Shiklomanov, I.A., 2000. Appraisal and assessment of world water resources. Water International 25, 11-32. https://doi.org/10.1080/02508060008686794

Smolders, R., Bervoets, L., De Boeck, G., Blust, R., 2002. Integrated condition indices as a measure of whole effluent toxicity in zebrafish (Danio rerio). Environmental Toxicology and Chemistry 21, 87-93. https://doi.org/10.1002/etc.5620210113

Sternberg, 1983. Biomedical Image Processing. Computer 16, 22-34. https://doi.org/10.1109/MC.1983.1654163

Sun, J., Wang, J., Zhang, R., Wei, D., Long, Q., Huang, Y., Xie, X., Li, A., 2017. Comparison of different advanced treatment processes in removing endocrine disruption effects from municipal wastewater secondary effluent. Chemosphere 168, 1-9. https://doi.org/https://doi.org/10.1016/j.chemosphere.2016.10.031

Sweeney, L., Voelkel, N.F., 2009. Estrogen exposure, obesity and thyroid disease in women with severe pulmonary hypertension. European Journal of Medical Research 14, 433442. https://doi.org/10.1186/2047-783x-14-10-433

Teta, C., Naik, Y.S., 2017. Vitellogenin induction and reduced fecundity in zebrafish exposed to effluents from the City of Bulawayo, Zimbabwe. Chemosphere 167, 282-290. https://doi.org/https://doi.org/10.1016/j.chemosphere.2016.10.011

Tetreault, G.R., Bennett, C.J., Cheng, C., Servos, M.R., McMaster, M.E., 2012. Reproductive and histopathological effects in wild fish inhabiting an effluent-dominated stream, Wascana Creek, SK, Canada. Aquatic Toxicology 110-111, 149-161. https://doi.org/https://doi.org/10.1016/j.aquatox.2012.01.004

Thorpe, K.L., Gross-Sorokin, M., Johnson, I., Brighty, G., Tyler, C.R., 2006. An assessment of the model of concentration addition for predicting the estrogenic activity of chemical mixtures in wastewater treatment works effluents. Environmental health perspectives 114 Suppl, 90-97. https://doi.org/10.1289/ehp.8059

Thorpe, K.L., Maack, G., Benstead, R., Tyler, C.R., 2009. Estrogenic wastewater treatment works effluents reduce egg production in fish. Environmental Science \& Technology 43, 2976-2982. https://doi.org/10.1021/es803103c

Tingaud-Sequeira, A., André, M., Forgue, J., Barthe, C., Babin, P.J., 2004. Expression 
patterns of three estrogen receptor genes during zebrafish (Danio rerio) development: Evidence for high expression in neuromasts. Gene Expression Patterns 4, 561-568. https://doi.org/https://doi.org/10.1016/j.modgep.2004.02.002

Trikić, M.Z., Monk, P., Roehl, H., Partridge, L.J., 2011. Regulation of zebrafish hatching by tetraspanin cd63. PLOS ONE 6, e19683.

Tyler, C.R., Jobling, S., 2008. Roach, sex, and gender-bending chemicals: The feminization of wild fish in English rivers. BioScience 58, 1051-1059. https://doi.org/10.1641/b581108

Tyler, C.R., van der Eerden, B., Jobling, S., Panter, G., Sumpter, J.P., 1996. Measurement of vitellogenin, a biomarker for exposure to oestrogenic chemicals, in a wide variety of cyprinid fish. Journal of Comparative Physiology B-Biochemical Systemic and Environmental Physiology 166, 418-426. https://doi.org/10.1007/BF02337886

Vajda, A.M., Barber, L.B., Gray, J.L., Lopez, E.M., Woodling, J.D., Norris, D.O., 2008. Reproductive disruption in fish downstream from an estrogenic wastewater effluent. Environmental Science \& Technology 42, 3407-3414. https://doi.org/10.1021/es0720661

Van den Belt, K., Berckmans, P., Vangenechten, C., Verheyen, R., Witters, H., 2004. Comparative study on the in vitro/in vivo estrogenic potencies of $17 \beta$-estradiol, estrone, 17a-ethynylestradiol and nonylphenol. Aquatic Toxicology 66, 183-195. https://doi.org/https://doi.org/10.1016/j.aquatox.2003.09.004

Versonnen, B.J., Janssen, C.R., 2004. Xenoestrogenic effects of ethinylestradiol in zebrafish (Danio rerio). Environmental Toxicology 19, 198-206. https://doi.org/https://doi.org/10.1002/tox.20012

Wilhelm, S., Jacob, S., Ziegler, M., Köhler, H.-R., Triebskorn, R., 2018. Influence of different wastewater treatment technologies on genotoxicity and dioxin-like toxicity in effluentexposed fish. Environmental Sciences Europe 30, 25. https://doi.org/10.1186/s12302018-0154-0

Williams, R.J., Churchley, J.H., Kanda, R., Johnson, A.C., 2012. Comparing predicted against measured steroid estrogen concentrations and the associated risk in two United Kingdom river catchments. Environmental Toxicology and Chemistry 31, 892-898. https://doi.org/10.1002/etc.1756

Yang, J., Li, H., Ran, Y., Chan K., 2014. Distribution and bioconcentration of endocrine disrupting chemicals in surface water and fish bile of the Pearl River Delta, South China. Chemosphere 107, 439-446. https://doi.org/10.1016/j.chemosphere.2014.01.048

Yuan, G., Liu, Y., Liu, G., Wei, L., Wen, Y., Huang, S., Guo, Y., Zou, F., Cheng, J., 2019. Associations between semen phytoestrogens concentrations and semen quality in Chinese men. Environment International 129, 136-144. https://doi.org/https://doi.org/10.1016/j.envint.2019.04.076

Zhou, Y., Zha, J., Wang, Z., 2012. Occurrence and fate of steroid estrogens in the largest wastewater treatment plant in Beijing, China. Environmental Monitoring and Assessment 184, 6799-6813. https://doi.org/10.1007/s10661-011-2459-y

Table 1. Details for the three WwTWs and physiochemical data for their discharged effluents. Details include the treatment processes $(\mathrm{AS}=$ activated sludge, $\mathrm{BF}=$ biological filter, $\mathrm{BAFF}=$ biological aerated flooded filter) used at each treatment works (including total hydraulic retention times [HRT], sludge retention times [SRT]), total population equivalent values for each site and types of industrial discharges. Data also include concentrations of the major steroidal oestrogens (E1, E2 and EE2) measured in the test effluents collected from the WwTW study sites during all experimental periods and 
calculated oestradiol equivalents (EEQs). Data are reported as mean \pm SE ( $n=3$ measurements per physiochemical parameter).

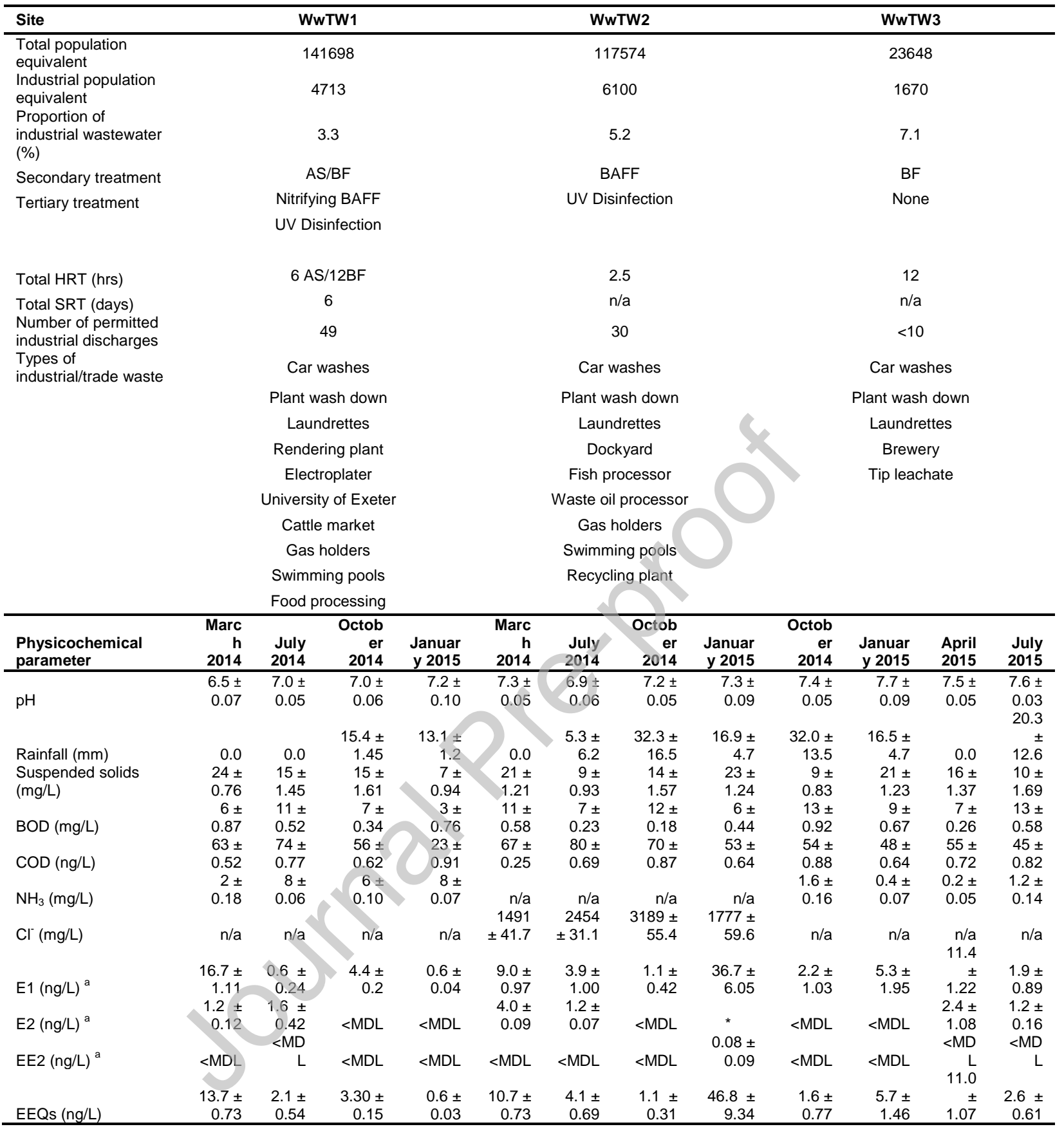

a The method detection limits (MDL) for E1, E2 and EE2 were $0.2 \mathrm{ng} / \mathrm{L}, 0.4 \mathrm{ng} / \mathrm{L}$ and $0.5 \mathrm{ng} / \mathrm{L}$,

respectively and the method quantification limits (MQL) for E1, E2 and EE2 were $0.6 \mathrm{ng} / \mathrm{L}, 1.2 \mathrm{ng} / \mathrm{L}$ and $1.5 \mathrm{ng} / \mathrm{L}$, respectively. To calculate mean oestrogen concentrations, concentrations that were over the limits of detection ( $\geq M D L$ ) but below the limits of quantification $(<M Q L)$ were assigned the MDL value. Concentrations below the MDL were considered to be zero. Individual measured concentrations of E1 and E2 are presented in Supplementary Table S3. EE2 concentrations were below the MDL $(0.5 \mathrm{ng} / \mathrm{L})$ throughout. * samples did not pass the quality control check and the qualifier ion could not be detected. 
$\mathrm{Ai}$

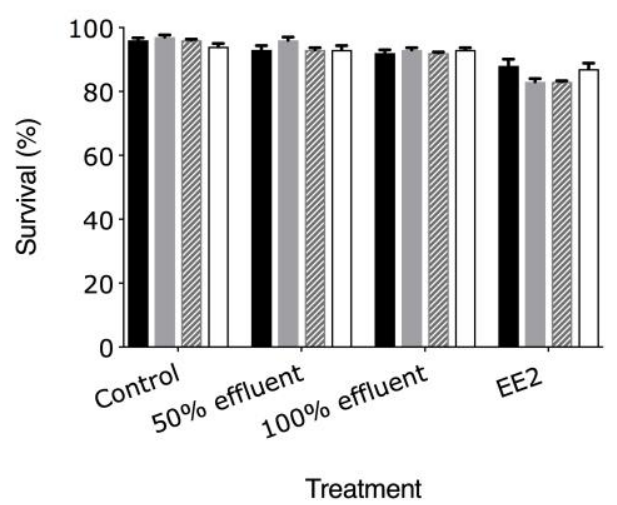

$\mathrm{Bi}$

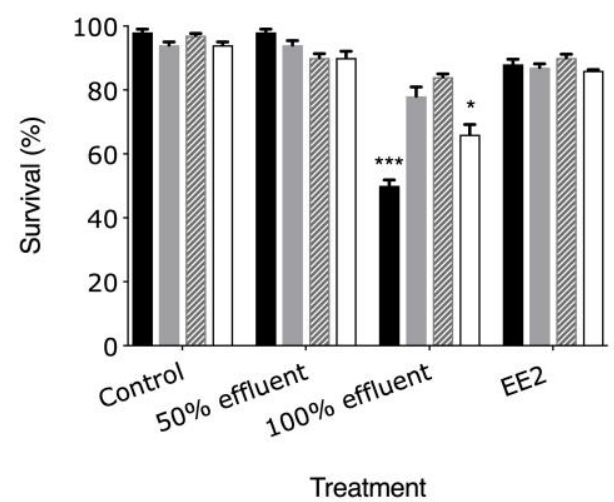

$\mathrm{Ci}$

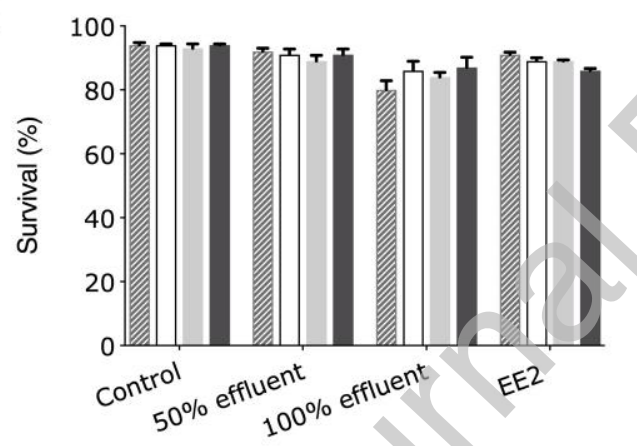

Treatment
Aii

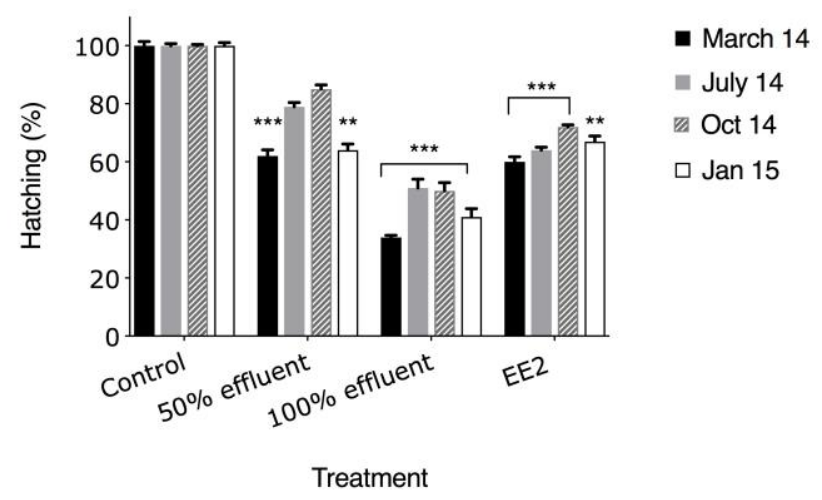

Bii

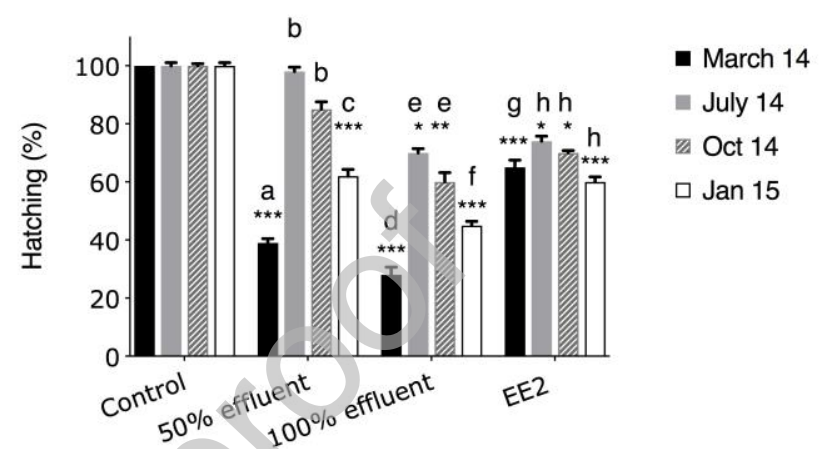

Cii

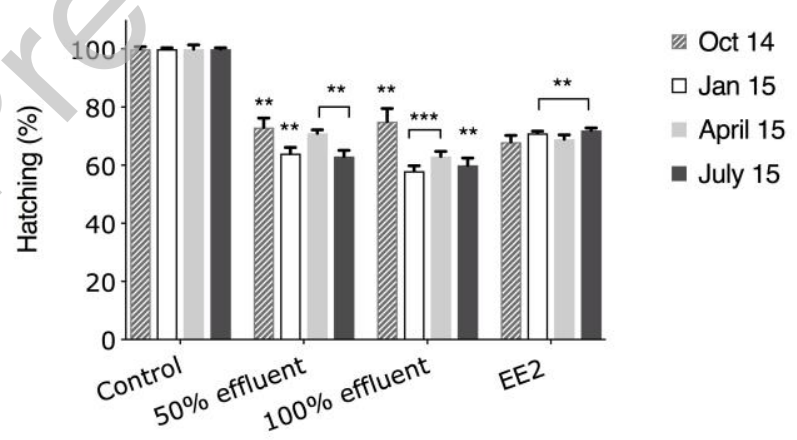

Treatment

Fig. 1. Hatching rates (at $72 \mathrm{hpf}$ ) and subsequent survival (at $96 \mathrm{hpf}$ ) in ERE-GFP zebrafish

embryos. Transgenic zebrafish embryos in control (unexposed), EE2 (10 ng/L, positive control) and effluent $(50 \%$ or $100 \%)$ from (A) WwTW1, (B) WwTW2 or (C) WwTW3. Effluent exposures were conducted using 24-hr composite wastewater effluent samples collected at 4-time points over a 12month period. Exposures were conducted in triplicate for any given effluent collection. Data are reported as mean $\pm \mathrm{SE}$ ( $\mathrm{n}=15$ fish per treatment). Asterisks denote a significant difference $\left({ }^{*} p<0.05,{ }^{* *} p<0.01\right.$, $\left.{ }^{* * *} p<0.001\right)$ compared with controls. Different letters denote a significant difference within treatment groups $(p-<0.05)$. 
Anterior (lateral)
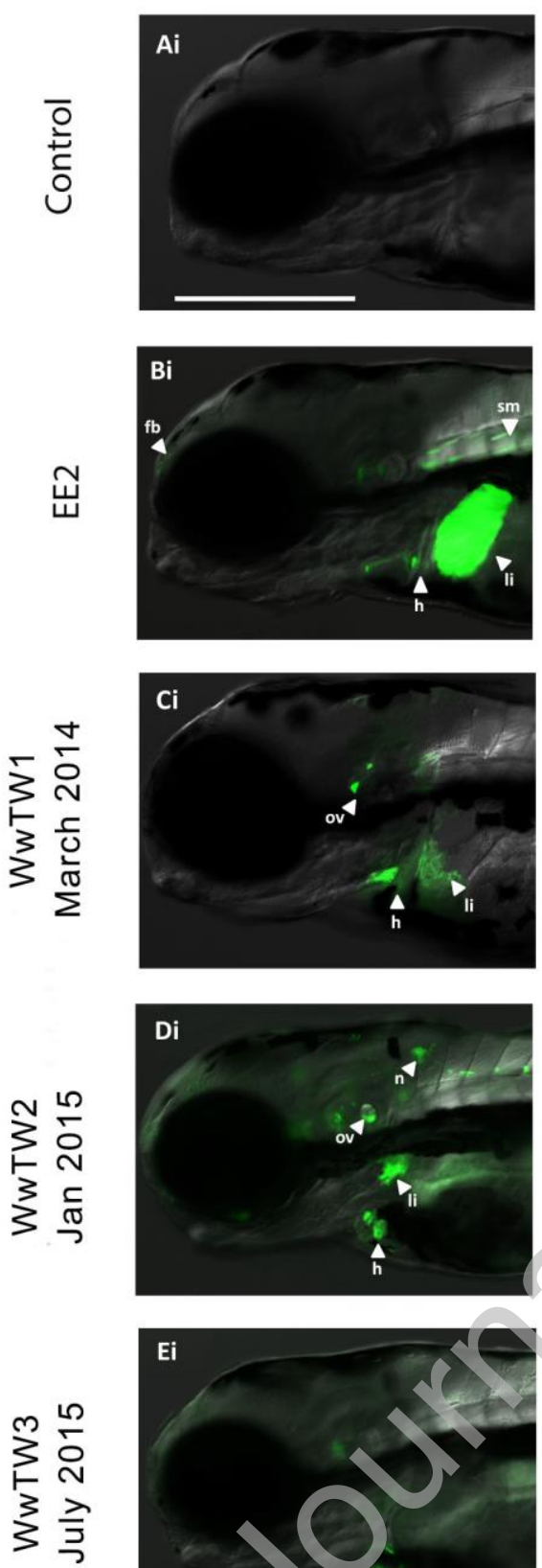

Anterior (ventral)
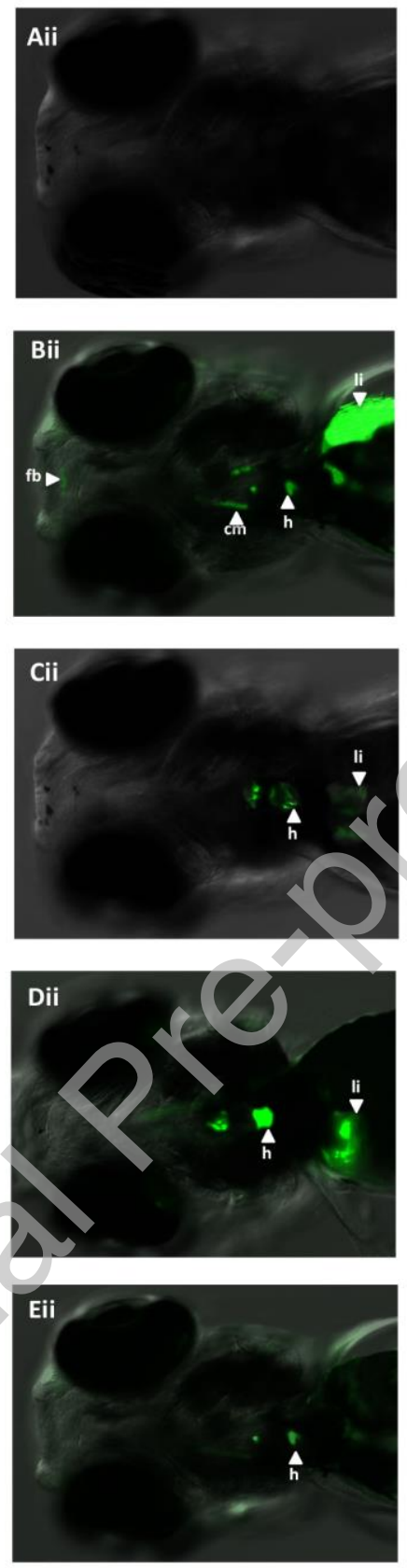

Trunk (lateral)
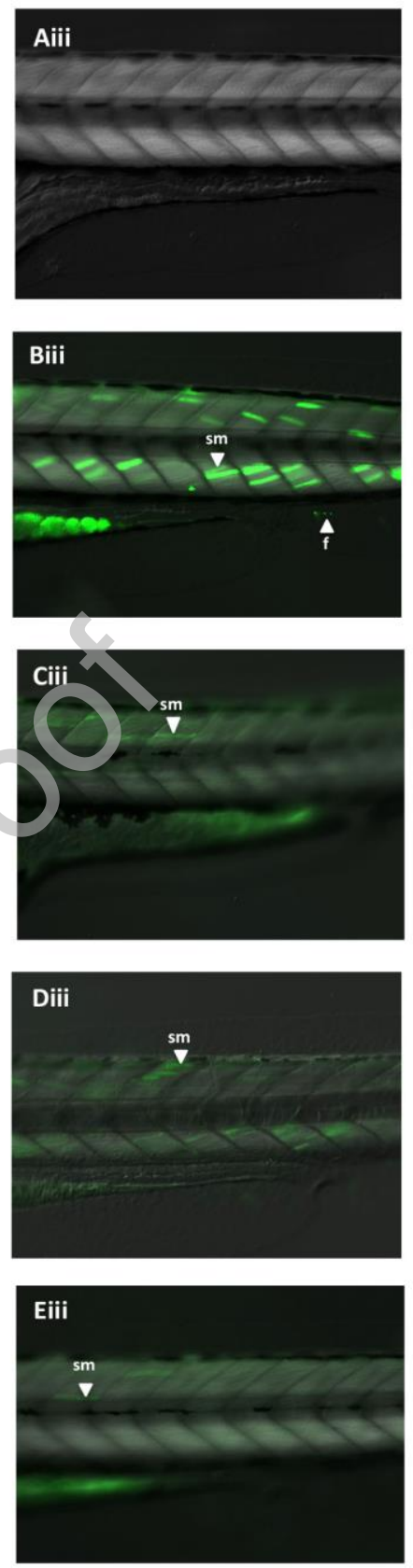

Fig 2. GFP in ERE-GFP zebrafish embryo-larvae exposed to three different wastewater effluents from fertilisation to $\mathbf{9 6}$ hours post fertilisation (hpf). Transgenic zebrafish embryo-larvae in control (unexposed) (A), EE2 (10 ng/L, positive control) (B), and wastewater effluent (100\%) exposed groups from WwTW1 (C), WwTW2 (D) and WwTW3 (E). Effluent exposures were conducted using 24-hr composite wastewater effluent samples collected at 4-time points over a 12-month period. GFP detection is shown for regions in the head (lateral (A-Ei) and ventral (A-Eii views) and trunk (lateral view A-Eiii). $\mathrm{cm}=$ cranial muscles; $f=$ fin; $f b=$ forebrain; $h=$ heart; li=liver; $n=$ neuromast; $o v=0$ tic vesicle; sm=somite muscles. Bar $=200 \mu \mathrm{m}$. 

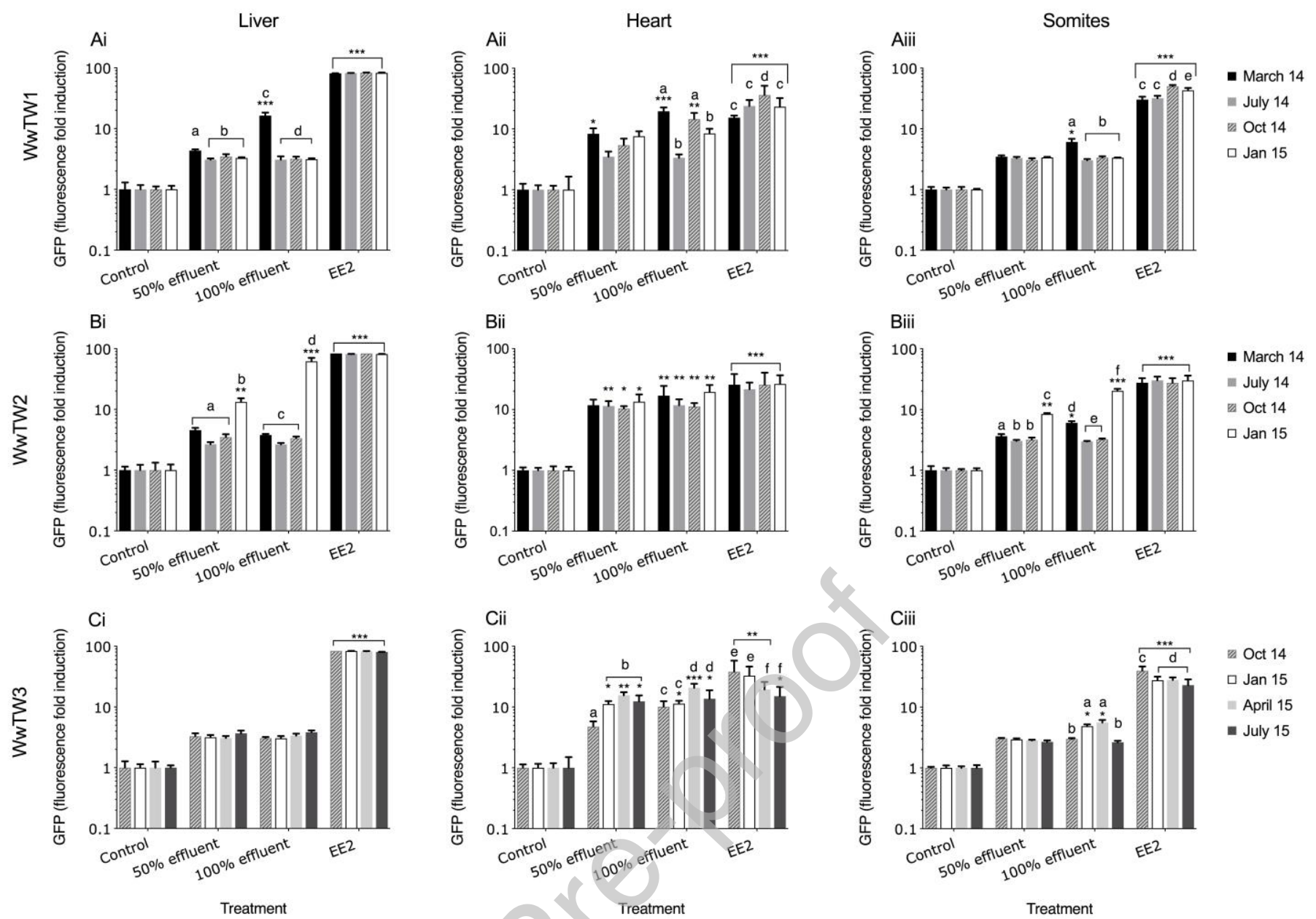

Fig 3. Quantification of GFP in target tissue responses in 96 hpf ERE-GFP zebrafish exposed to three different wastewater effluents, as determined by fluorescence induction. Data show foldincrease in GFP levels relative to controls in the liver (i), heart (ii) and somites (iii) in ERE-GFP larvae exposed to EE2 (10 ng/l or WwTW effluent $(50 \%$ or $100 \%$ ) from WwTW1(A), WwTW2 (B) and WwTW3 (C). Effluent exposures were conducted using 24-hr composite wastewater effluent samples collected at 4-time points over a 12-month period. Exposures were conducted in triplicate for any given effluent collection. Data are reported as mean $\pm S E$ ( $n=15$ fish per treatment). Asterisks denote a significant difference $\left({ }^{*} p<0.05,{ }^{* *} p<0.01,{ }^{* * *} p<0.001\right)$ compared with controls. Different letters denote a significant difference within treatment groups $(p<0.05)$. 
A

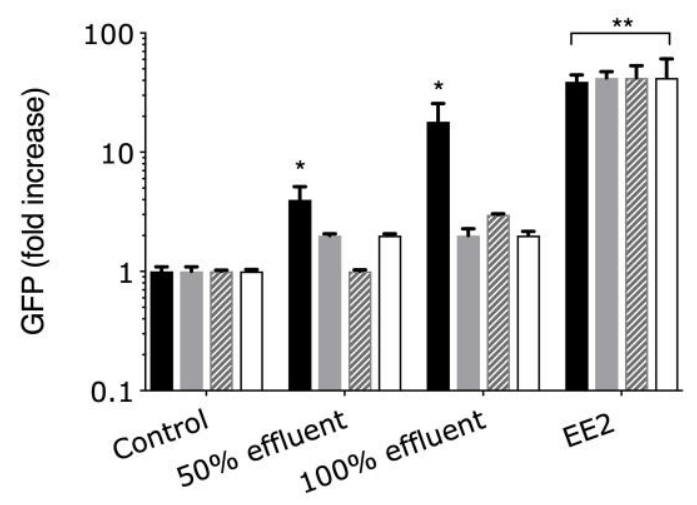

- March 14

- July 14

Oct 14

Jan 15

Treatment

B

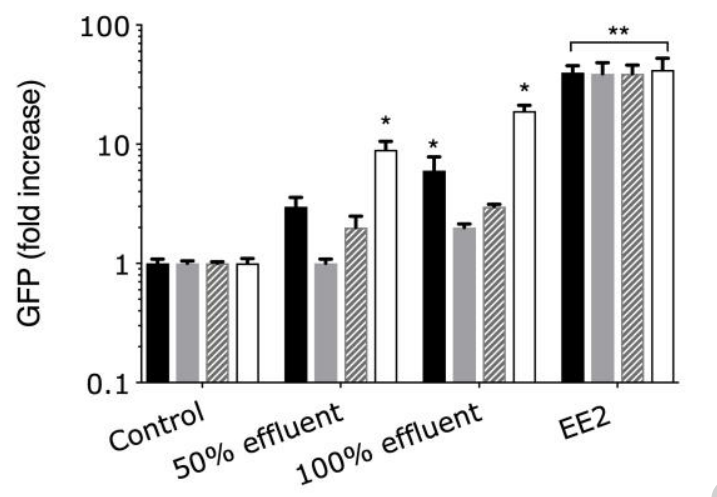

- March 14

- July 14

Oct 14

Jan 15

\section{Treatment}

C

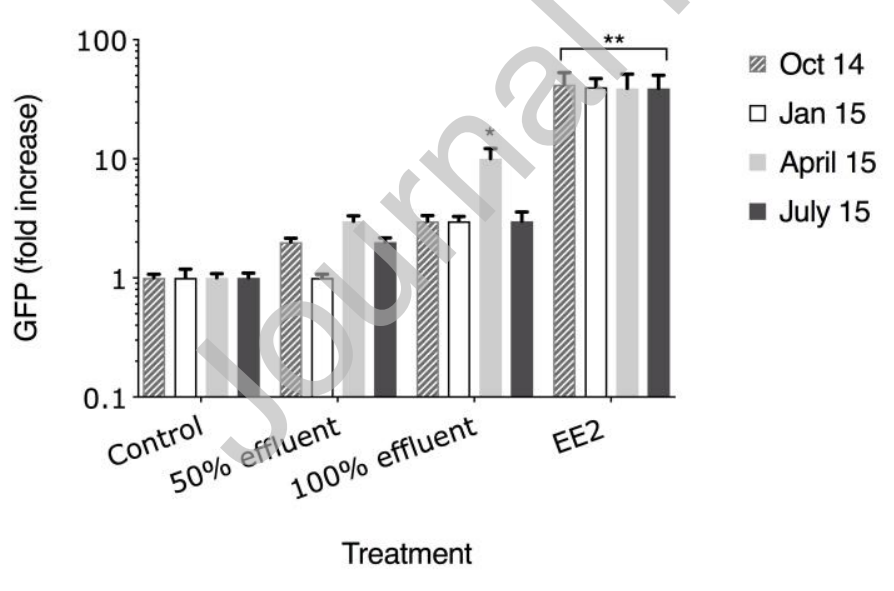

Fig 4. Relative GFP levels in whole ERE-GFP zebrafish embryos exposed to selected WwTW effluents and EE2, as quantified through Western blotting. Data show fold-increase in GFP expression compared with controls following exposure to EE2 (10 ng/l) or WwTW effluent $(50 \%$ or 100\%) from WwTW1 (A), WwTW2 (B) and WwTW3 (C). Effluent exposures were conducted using 24-hr composite wastewater effluent samples collected at 4-time points over a 12-month period. Exposures were conducted three times for any given effluent collection. Data are reported as mean \pm SE $(n=15$ fish per treatment). Asterisks denote a significant difference $\left({ }^{*} p<0.05,{ }^{* *} p<0.01\right.$ ) compared with controls. 
$\mathrm{Ai}$

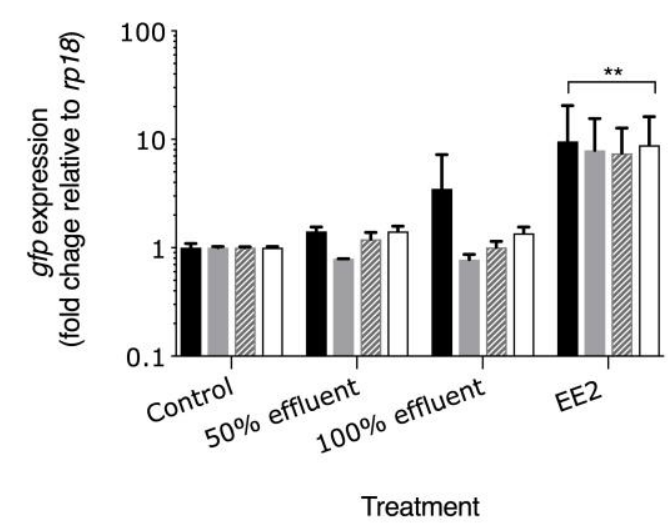

$\mathrm{Bi}$

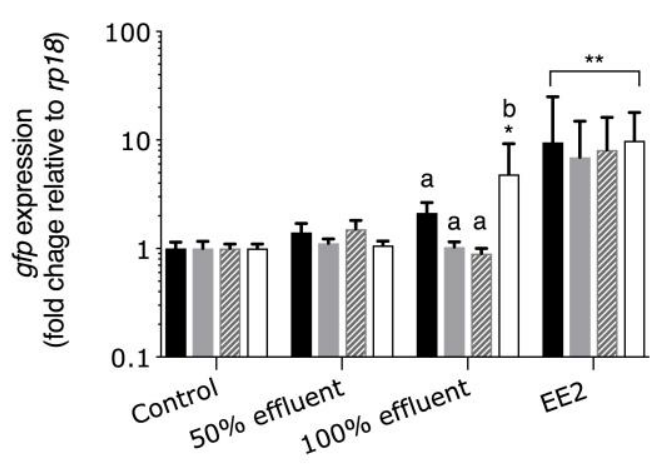

Treatment

$\mathrm{Ci}$

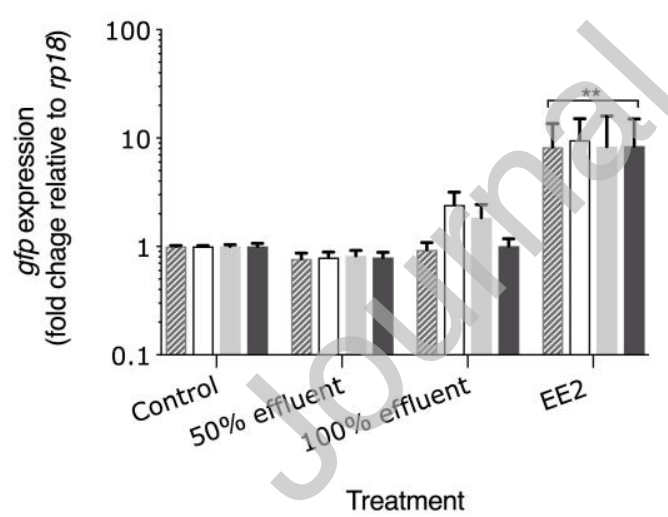

Aii

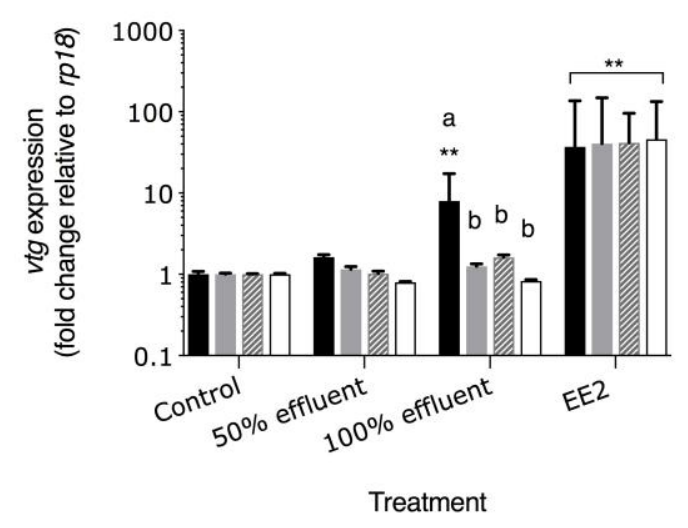

Bii

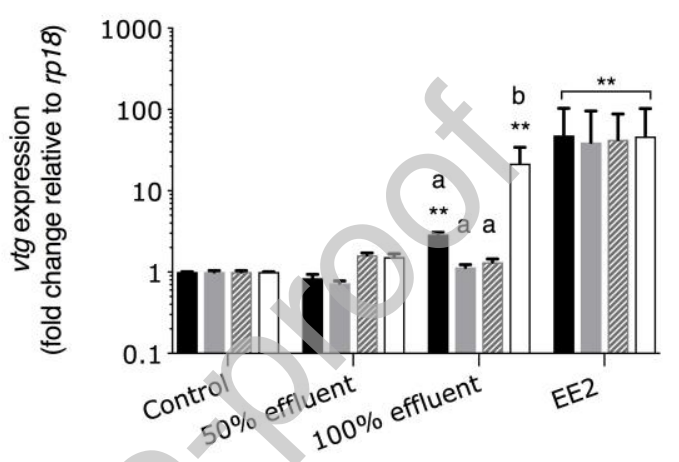

- March 14

- July 14

act 14

$\square \operatorname{Jan} 15$

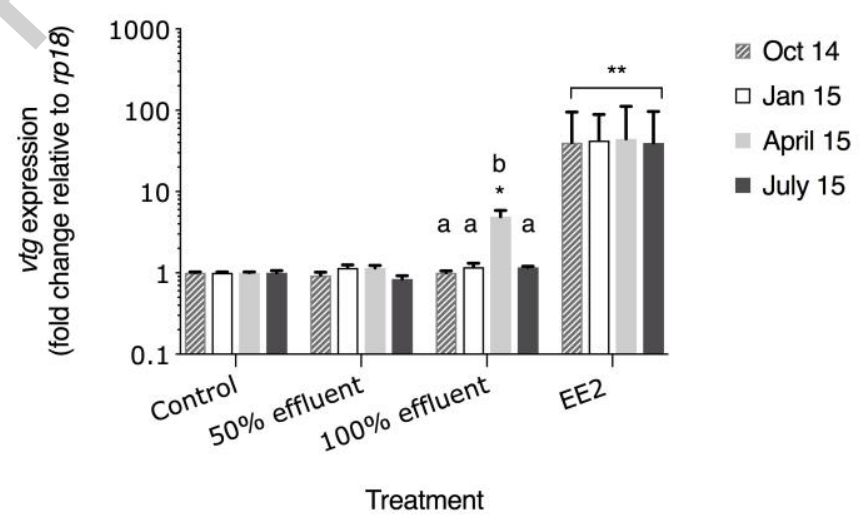

Fig. 5. gfp and vtg mRNA levels in whole ERE-GFP zebrafish embryo-larvae. Data show average fold-changes (normalised against the expression of the control gene ribosomal protein L8 (rp/8) compared with controls following exposure to EE2 (10 ng/l) or WwTW effluent (50\% or $100 \%)$ for WwTW1 (Ai-ii), WwTW2 (Bi-ii) and WwTW3 (Ci-ii). Effluent exposures were conducted using 24-hr composite wastewater effluent samples collected at 4-time points over a 12-month period. Exposures were conducted in triplicate for any given effluent collection. Data are reported as means $\pm S E(n=15$ fish per treatment). Asterisks denote a significant difference $\left({ }^{*} p<0.05,{ }^{* *} p<0.01\right)$ compared with treatment controls at the relevant time point. Different letters denote a significant difference within groups 

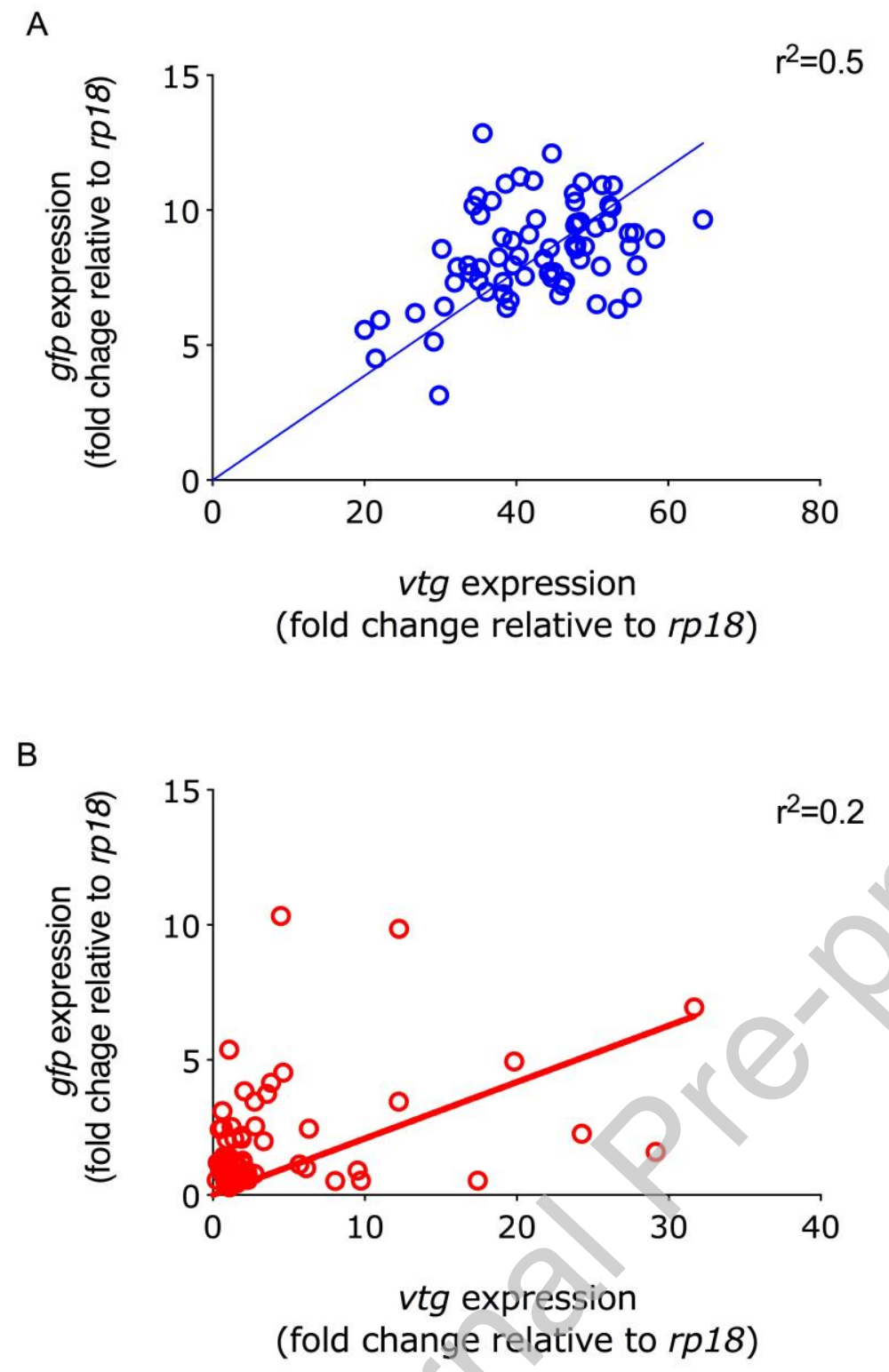

Fig 6. Correlation between gfp mRNA and vtg mRNA levels in ERE-GFP zebrafish whole embryos. Data show (A) EE2 (10 ng/l, positive control) treatment groups ( $n=15$ fish) and (B) effluent (50\% \& 100\% combined; $n=15$ fish per treatment) treatments groups for the three WwTWs. Effluent exposures were conducted using 24-hr composite wastewater effluent samples collected at 4-time points over a 12-month period. Exposures were conducted in triplicate for any given effluent collection. 